\title{
LEVEL II SCOUR ANALYSIS FOR BRIDGE 34 (BRNATH00290034) on TOWN HIGHWAY 29, crossing LOCUST CREEK, BARNARD, VERMONT
}

U.S. Geological Survey Open-File Report 96-642

Prepared in cooperation with

VERMONT AGENCY OF TRANSPORTATION and

FEDERAL HIGHWAY ADMINISTRATION 


\section{LEVEL II SCOUR ANALYSIS FOR BRIDGE 34 (BRNATH00290034) on TOWN HIGHWAY 29, crossing LOCUST CREEK, BARNARD, VERMONT}

By Michael A. Ivanoff and Matthew A. Weber

\section{U.S. Geological Survey Open-File Report 96-642}

Prepared in cooperation with

VERMONT AGENCY OF TRANSPORTATION and

FEDERAL HIGHWAY ADMINISTRATION 


\title{
U.S. DEPARTMENT OF THE INTERIOR BRUCE BABBITT, Secretary
}

\author{
U.S. GEOLOGICAL SURVEY \\ Gordon P. Eaton, Director
}

For additional information write to:

District Chief

U.S. Geological Survey 361 Commerce Way

Pembroke, NH 03275-3718
Copies of this report may be purchased from:

U.S. Geological Survey

Branch of Information Services

Open-File Reports Unit

Box 25286

Denver, CO 80225-0286 


\section{CONTENTS}

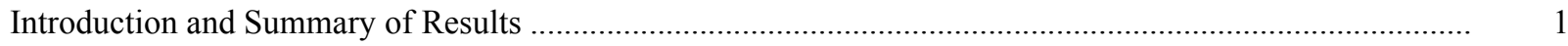

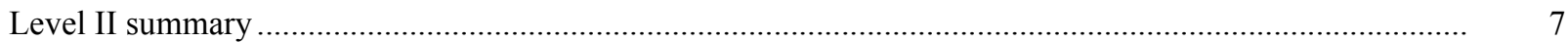

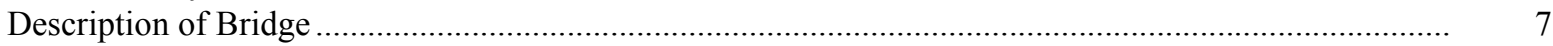

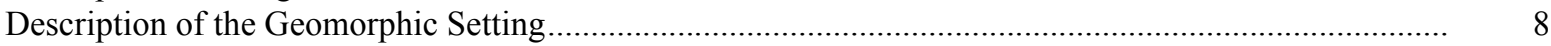

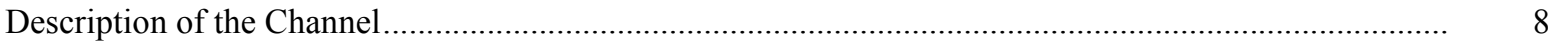

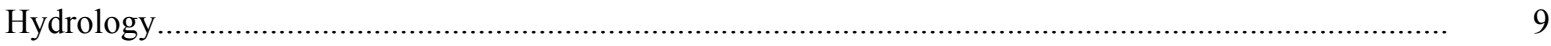

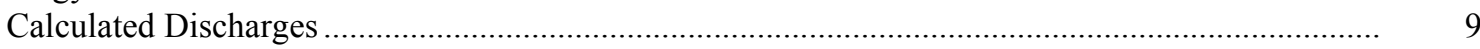

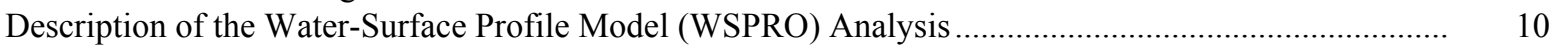

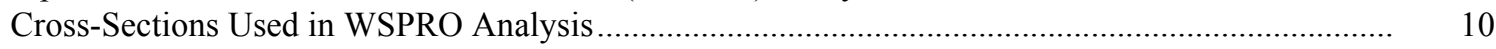

Data and Assumptions Used in WSPRO Model ...................................................................... 11

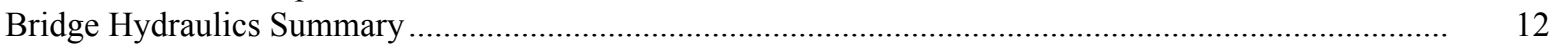

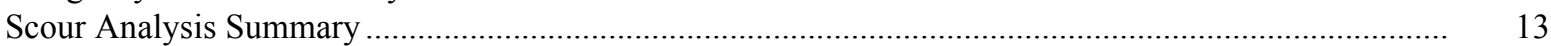

Special Conditions or Assumptions Made in Scour Analysis ...................................................... 13

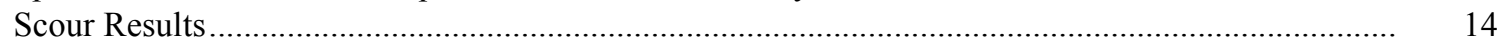

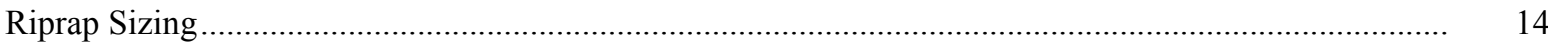

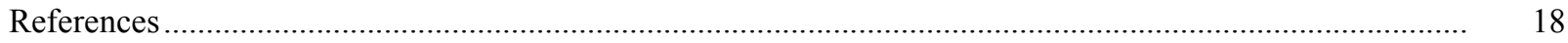

Appendixes:

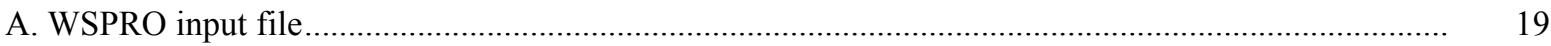

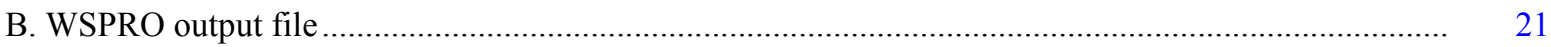

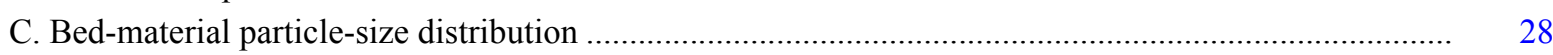

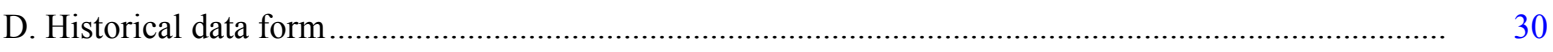

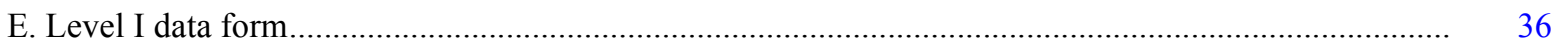

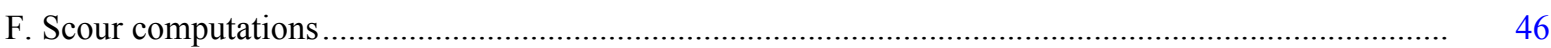

\section{FIGURES}

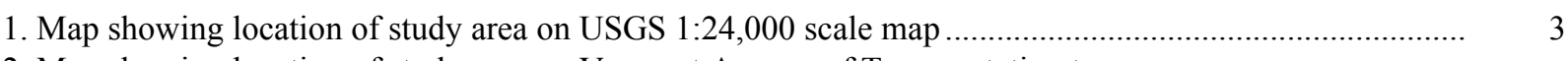

2. Map showing location of study area on Vermont Agency of Transportation town
highway map

3. Structure BRNATH00290034 viewed from upstream (October 13, 1994) ............................................ 5

4. Downstream channel viewed from structure BRNATH00290034 (October 13, 1994). .......................... 5

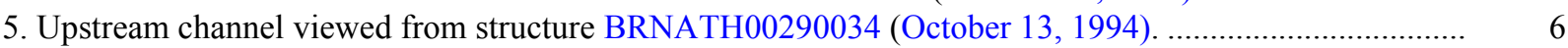

6. Structure BRNATH00290034 viewed from downstream (October 13, 1994)...................................... 6

7. Water-surface profiles for the 100- and 500-year discharges at structure

BRNATH00290034 on Town Highway 29, crossing Locust Creek,

Barnard, Vermont.

8. Scour elevations for the 100- and 500-year discharges at structure

BRNATH00290034 on Town Highway 29, crossing Locust Creek,

Barnard, Vermont.

\section{TABLES}

1. Remaining footing/pile depth at abutments for the 100-year discharge at structure

BRNATH00290034 on Town Highway 29, crossing Locust Creek,

Barnard, Vermont.

2. Remaining footing/pile depth at abutments for the 500-year discharge at structure

BRNATH00290034 on Town Highway 29, crossing Locust Creek,

Barnard, Vermont.

5
(5) 


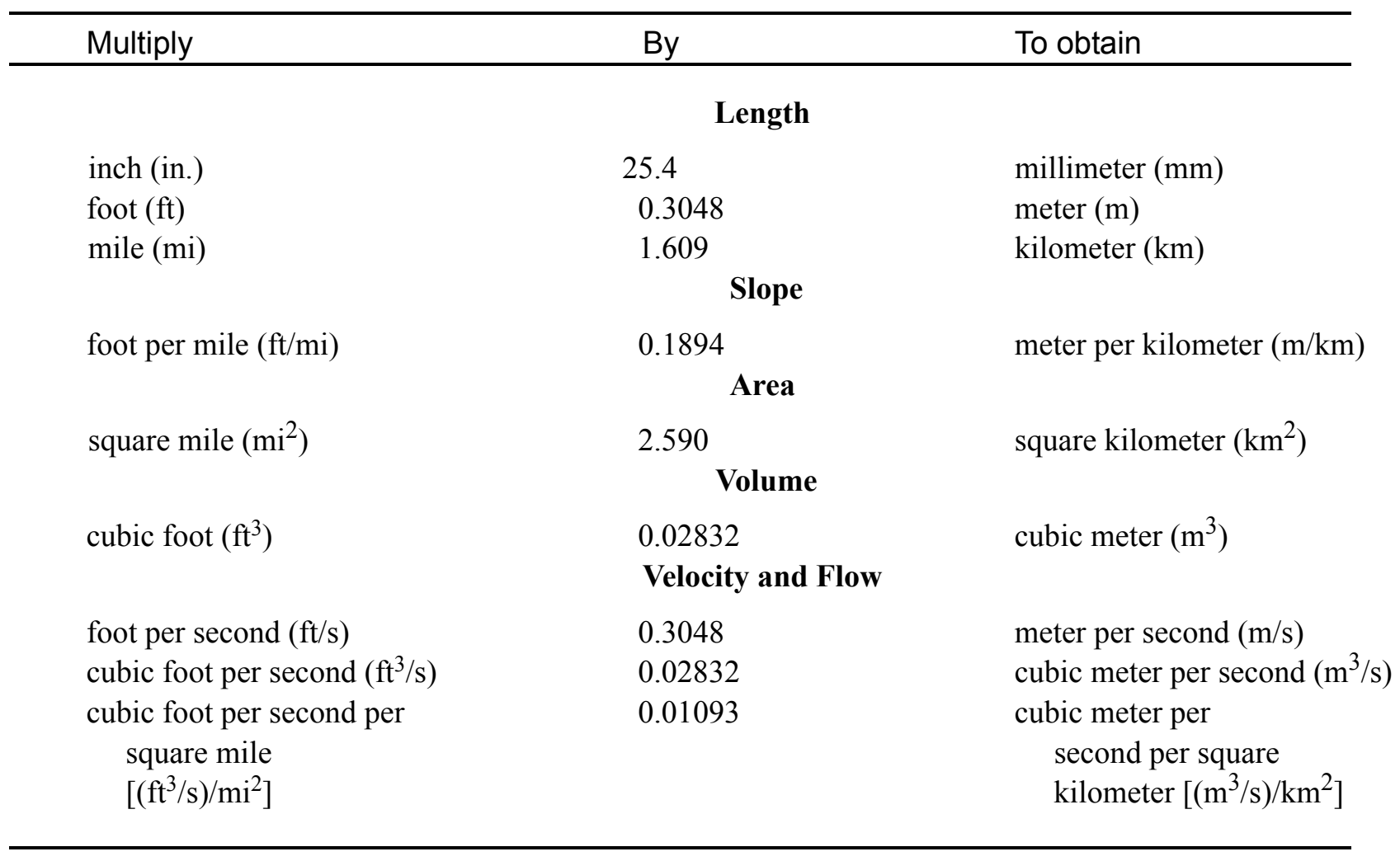

\section{OTHER ABBREVIATIONS}

$\begin{array}{lrlr}\mathrm{BF} & \text { bank full } & \text { LWW } & \text { left wingwall } \\ \mathrm{cfs} & \text { cubic feet per second } & \text { MC } & \text { main channel } \\ \mathrm{D}_{50} & \text { median diameter of bed material } & \text { RAB } & \text { right abutment } \\ \mathrm{DS} & \text { downstream } & \text { RABUT } & \text { face of right abutment } \\ \mathrm{elev} & \text { elevation } & \text { RB } & \text { right bank } \\ \mathrm{f} / \mathrm{p} & \text { flood plain } & \text { ROB } & \text { right overbank } \\ \mathrm{ft}^{2} & \text { square feet } & \text { RWW } & \text { right wingwall } \\ \mathrm{ft} / \mathrm{ft} & \text { feet per foot } & \text { TH } & \text { town highway } \\ \mathrm{JCT} & \text { junction } & \text { UB } & \text { under bridge } \\ \mathrm{LAB} & \text { left abutment } & \text { US } & \text { upstream } \\ \mathrm{LABUT} & \text { face of left abutment } & \text { USGS } & \text { United States Geological Survey } \\ \mathrm{LB} & \text { left bank } & \text { VTAOT Vermont Agency of Transportation } \\ \mathrm{LOB} & \text { left overbank } & \text { WSPRO } & \text { water-surface profile model }\end{array}$

In this report, the words "right" and "left" refer to directions that would be reported by an observer facing downstream. Sea level: In this report, "sea level" refers to the National Geodetic Vertical Datum of 1929-- a geodetic datum derived from a general adjustment of the first-order level nets of the United States and Canada, formerly called Sea Level Datum of 1929.

In the appendices, the above abbreviations may be combined. For example, USLB would represent upstream left bank. 


\title{
LEVEL II SCOUR ANALYSIS FOR BRIDGE 34 (BRNATH00290034) ON TOWN HIGHWAY 29, CROSSING LOCUST CREEK, BARNARD, VERMONT
}

\author{
By Michael A. Ivanoff and Matthew A. Weber
}

\section{INTRODUCTION AND SUMMARY OF RESULTS}

This report provides the results of a detailed Level II analysis of scour potential at structure BRNATH00290034 on Town Highway 29 crossing Locust Creek, Barnard, Vermont (figures 1-8). A Level II study is a basic engineering analysis of the site, including a quantitative analysis of stream stability and scour (U.S. Department of Transportation, 1993). Results of a Level I scour investigation also are included in Appendix E of this report. A Level I investigation provides a qualitative geomorphic characterization of the study site. Information on the bridge, gleaned from Vermont Agency of Transportation (VTAOT) files, was compiled prior to conducting Level I and Level II analyses and is found in Appendix D.

The site is in the Green Mountain section of the New England physiographic province in central Vermont. The $11.5-\mathrm{mi}^{2}$ drainage area is in a predominantly rural and forested basin. In the vicinity of the study site, the surface cover is forest, except for pasture on the downstream right overbank.

In the study area, Locust Creek has an incised, generally straight channel with a slope of approximately $0.03 \mathrm{ft} / \mathrm{ft}$, an average channel top width of $64 \mathrm{ft}$ and an average channel depth of $7 \mathrm{ft}$. The predominant channel bed materials are gravel and cobble with a median grain size $\left(\mathrm{D}_{50}\right)$ of $89.3 \mathrm{~mm}(0.293 \mathrm{ft})$. The geomorphic assessment at the time of the Level I and Level II site visit on October 13, 1994 and December 16, 1994, indicated that the reach was stable.

The Town Highway 29 crossing of Locust Creek is a 37-ft-long, one-lane bridge consisting of one 32-foot concrete span (Vermont Agency of Transportation, written communication, August 23, 1994). The bridge is supported by vertical, concrete abutments with wingwalls. The channel is skewed approximately 25 degrees to the opening while the opening-skew-toroadway is 25 degrees.

There was no observable scour protection measure at the site. Additional details describing conditions at the site are included in the Level II Summary and Appendices D and E. 
Scour depths and rock rip-rap sizes were computed using the general guidelines described in Hydraulic Engineering Circular 18 (Richardson and others, 1995). Total scour at a highway crossing is comprised of three components: 1) long-term streambed degradation; 2) contraction scour (due to accelerated flow caused by a reduction in flow area at a bridge) and; 3) local scour (caused by accelerated flow around piers and abutments). Total scour is the sum of the three components. Equations are available to compute depths for contraction and local scour and a summary of the results of these computations follows.

Contraction scour for all modelled flows ranged from 0.0 to $2.0 \mathrm{ft}$. The worst-case contraction scour occurred at the incipient-overtopping discharge. Abutment scour ranged from 11.7 to $16.9 \mathrm{ft}$. The worst-case abutment scour occurred at the incipient-overtopping discharge. Additional information on scour depths and depths to armoring are included in the section titled "Scour Results". Scoured-streambed elevations, based on the calculated scour depths, are presented in tables 1 and 2. A cross-section of the scour computed at the bridge is presented in figure 8 . Scour depths were calculated assuming an infinite depth of erosive material and a homogeneous particle-size distribution.

It is generally accepted that the Froehlich equation (abutment scour) gives "excessively conservative estimates of scour depths" (Richardson and others, 1995, p. 47). Usually, computed scour depths are evaluated in combination with other information including (but not limited to) historical performance during flood events, the geomorphic stability assessment, existing scour protection measures, and the results of the hydraulic analyses. Therefore, scour depths adopted by VTAOT may differ from the computed values documented herein. 


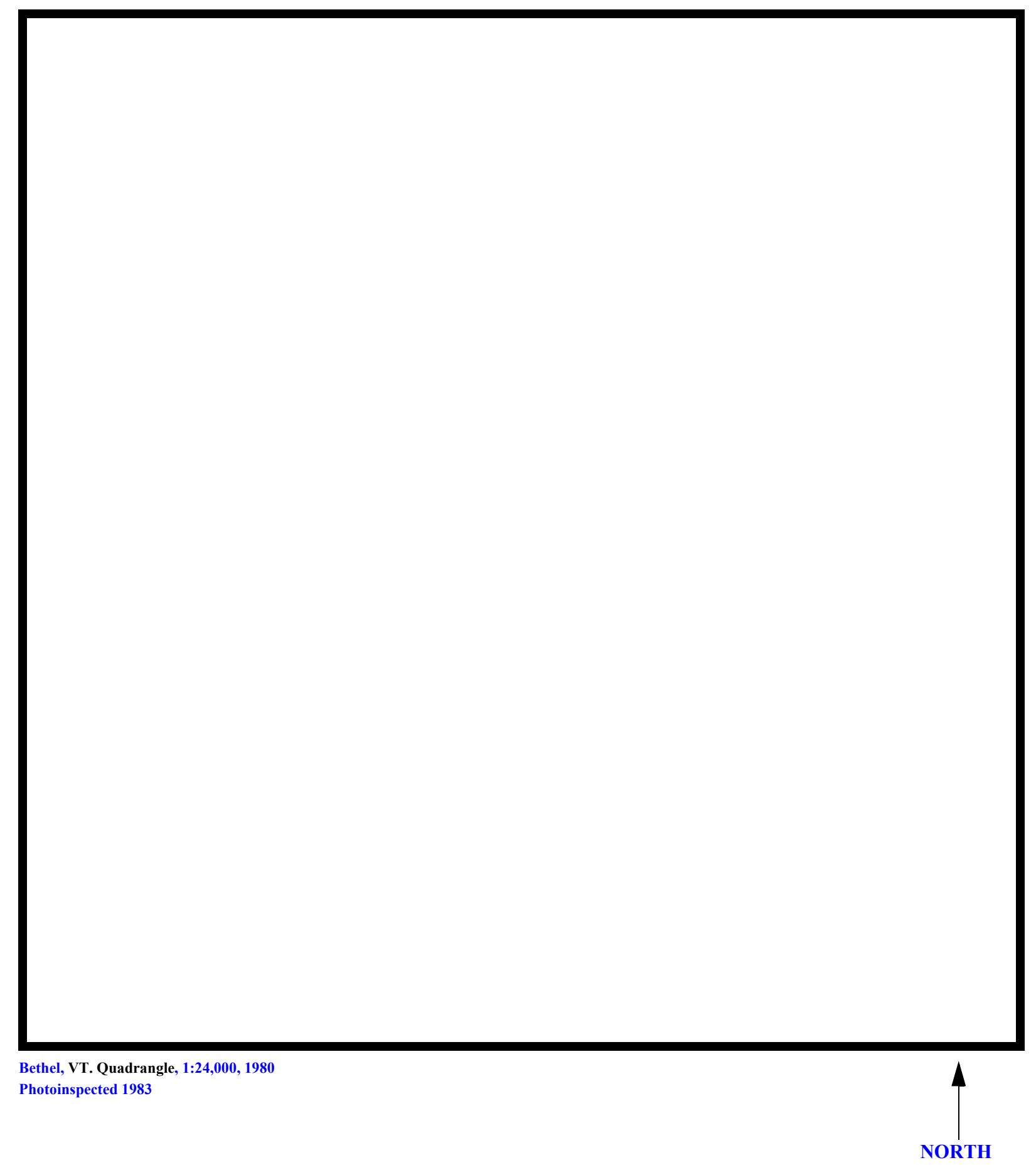

Figure 1. Location of study area on USGS 1:24,000 scale map. 
Figure 2. Location of study area on Vermont Agency of Transportation town highway map. 

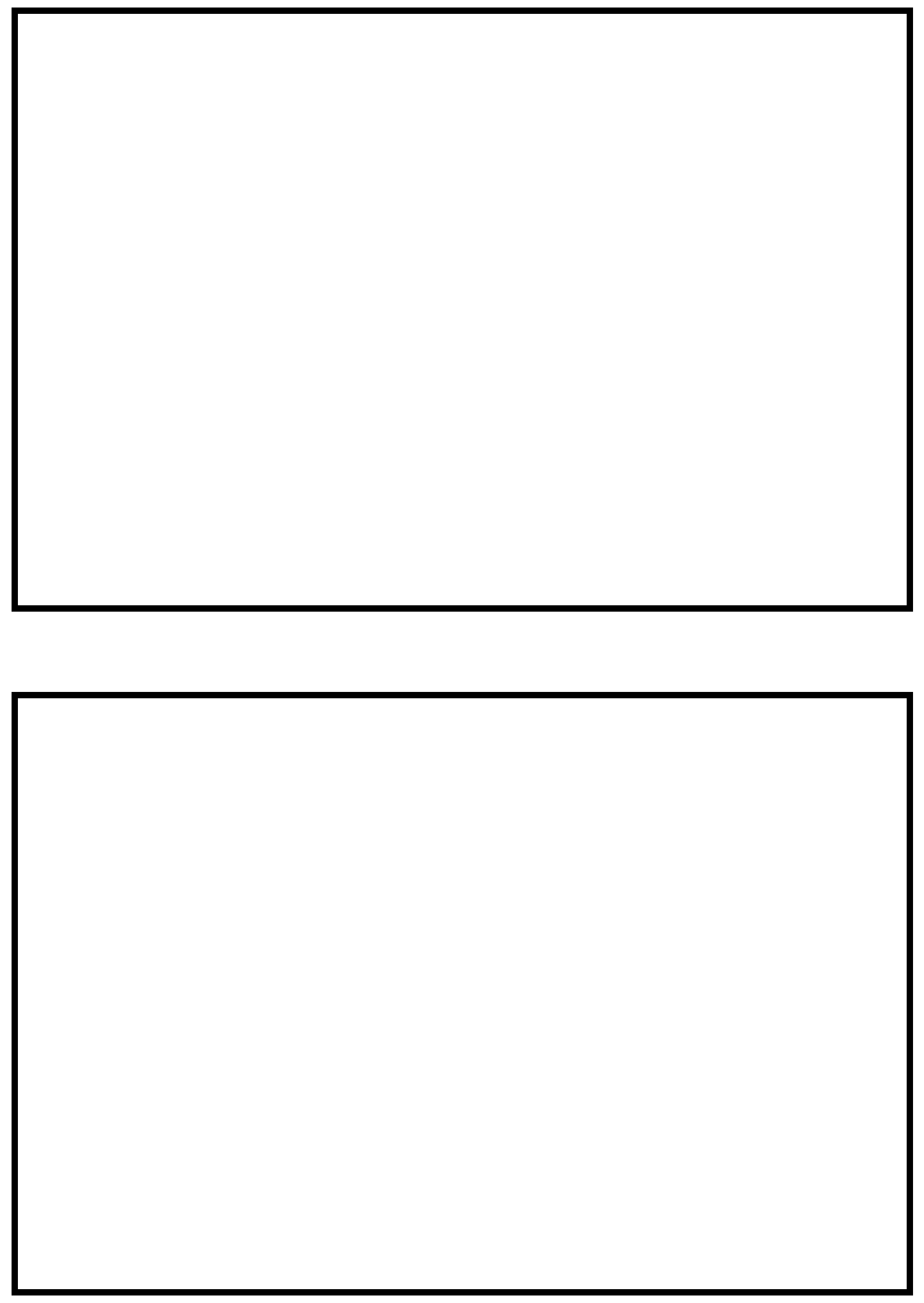

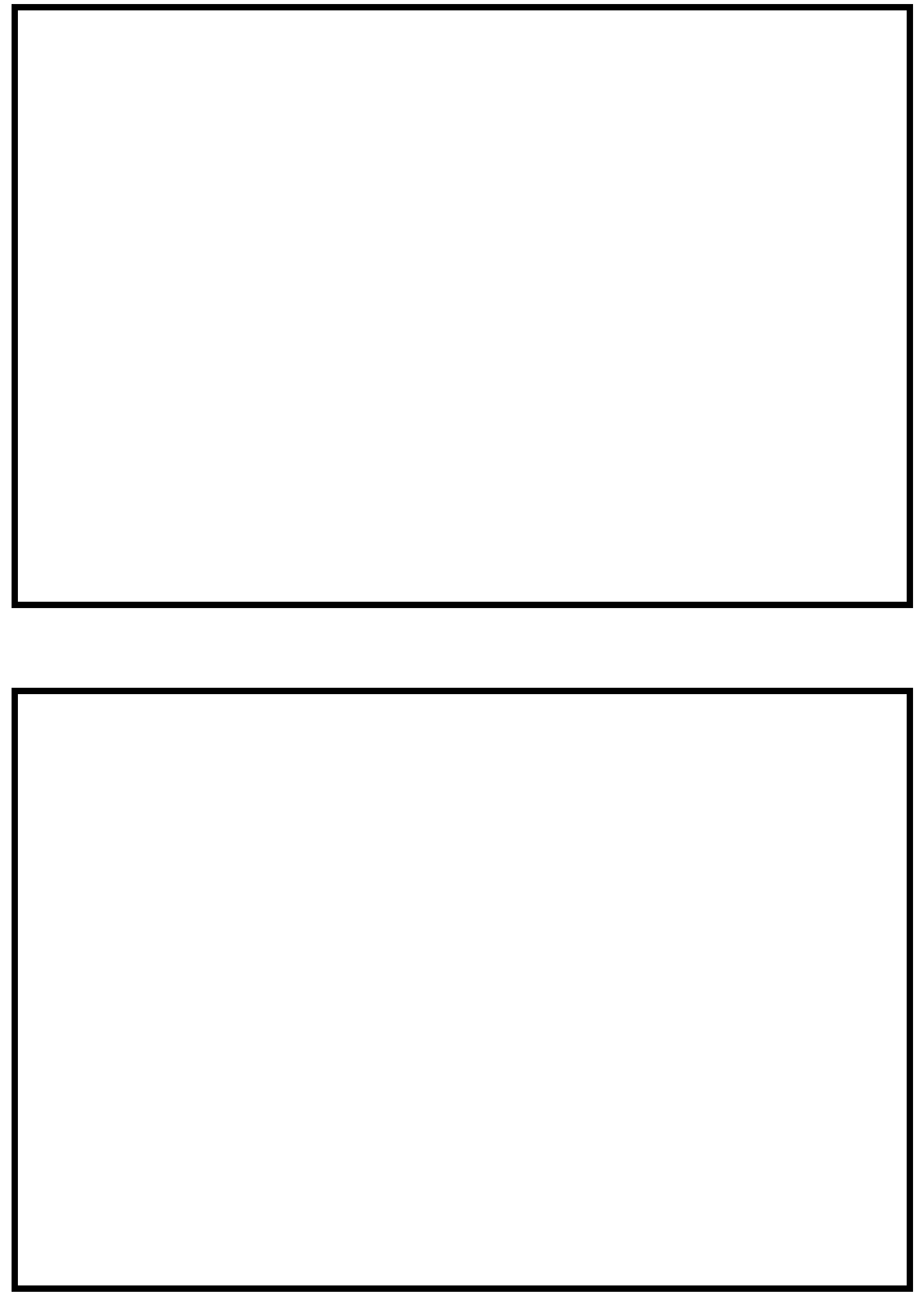


\section{LEVEL II SUMMARY}

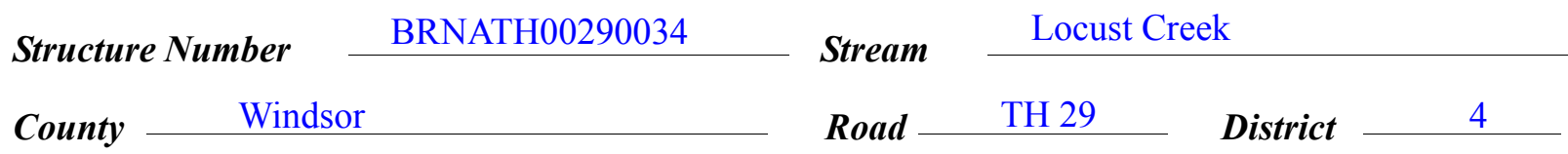

\section{Description of Bridge}

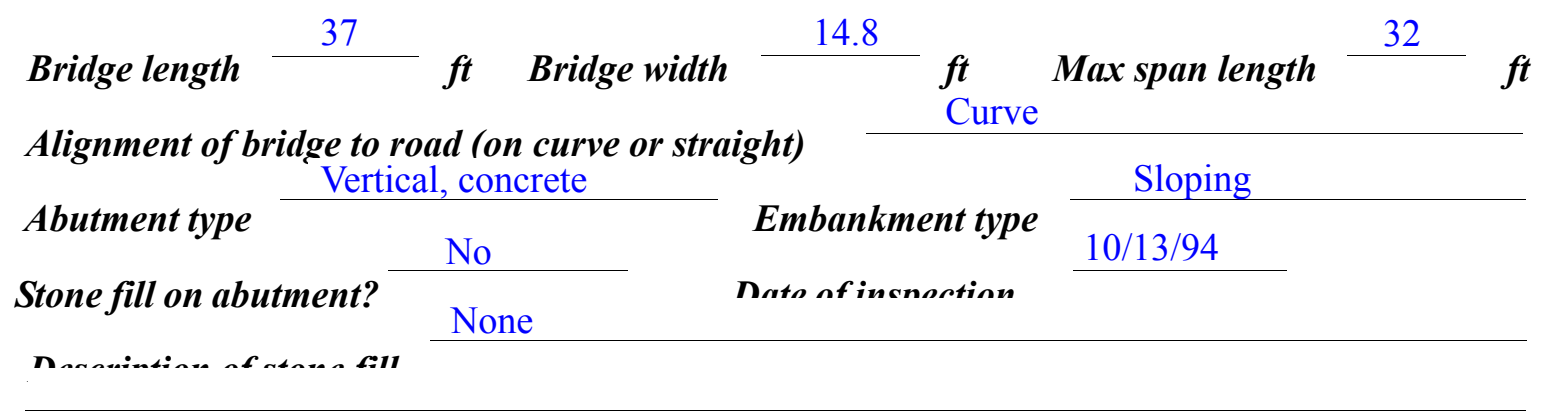

Abutments and wingwalls are concrete. The top of the

right abutment footing, downstream end is exposed, level with the bed material.

Is bridge skewed to flood flow according to $\mathrm{No}^{\text {'survey? }}$

Debris accumulation on bridge at time of Level I or Level II site visit:

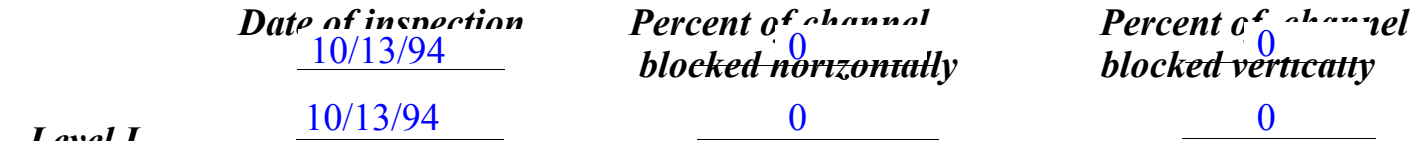

Level II $\quad$ Moderate. The upstream reach is forested with some trees leaning into the channel.

Potential for debris

The stream flow impacts the right abutment with the top of the footing exposed at the Doscriho anv, foaturos noar ar at tho hridoo that mav, affort flow, (includo ahsorvation dato) downstream end. 10/13/94 


\section{Description of the Geomorphic Setting}

General topography The channel has a flat to slightly irregular floodplain with steep valley walls on both sides.

Geomorphic conditions at bridge site: downstream (DS), upstream (US)

Date of inspection $\quad 10 / 13 / 94 \& 12 / 16 / 94$

DS left: $\quad$ Steep valley wall

DS right: $\quad$ Moderately sloping channel bank to a narrow terrace

US left: $\quad$ Steep channel bank to floodplain

US right: $\quad$ Steep valley wall

\section{Description of the Channel}

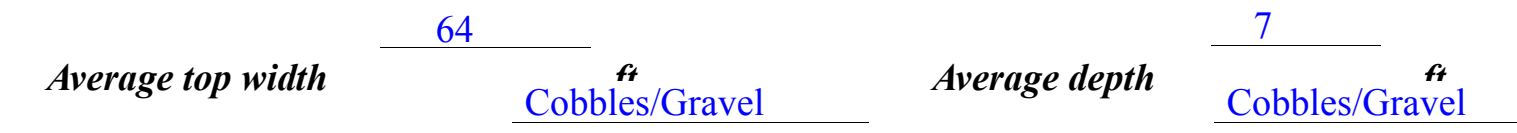

Predominant bed material

Bank material

Straight, perennial

stream with sémi-alluvial channel boundaries.

$10 / 13 / 94 \& 12 / 16 / 96$

Vegetative co ${ }^{1}$ Trees

DS left: $\quad$ Trees and brush

DS right: $\quad$ Trees

US left: $\quad$ Trees.

US right: $\quad$ Yes

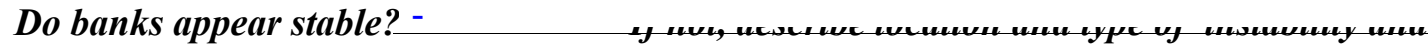

date of observation.

13/94 and 12/16/96 noted a side bar under the bridge.

Describe any obstructions in channel and date of observation. 


\section{Hydrology}

Drainage area $\frac{11.5}{m^{2}}{ }^{2}$

Percentage of drainage area in physiographic provinces: (approximate)

Physiographic province/section

New England/ Green Mountain
Percent of drainage area 100

Is drainage area considered rural or urban? Rural Describe any significant urbanization:

Is there a USGS gage on the stream of interest?

No

USGS gage description

USGS gage number

Gage drainage area $\mathrm{mi}^{2}$

Is there a lake/p

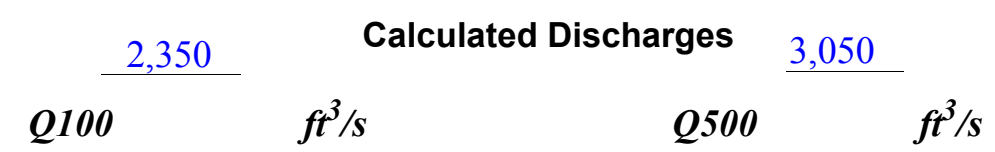

The 100-year discharge is from the VTAOT extrapolated and compared to other empirical methods (Benson, 1962; Johnson and Tasker, 1974; FHWA, 1983; Potter, 1957a\&b; Talbot, 1887). 


\section{Description of the Water-Surface Profile Model (WSPRO) Analysis}

Datum for WSPRO analysis (USGS survey, sea level, VTAOT plans)

USGS survey

Datum tie between USGS survey and VTAOT plans

Subtract 3 feet from USGS survey

to obtain VTAOT plans' datum.

Description of reference marks used to determine USGS datum. $\quad$ RM1 is a chiseled X in a

chiseled square on top of the upstream end of the right abutment (elev. $500.02 \mathrm{ft}$, arbitrary

survey datum). RM2 is a chiseled $\mathrm{X}$ in a chiseled square on top of the downstream end of the

left abutment (elev. $501.31 \mathrm{ft}$, arbitrary survey datum).

\section{Cross-Sections Used in WSPRO Analysis}

\begin{tabular}{|c|c|c|c|}
\hline${ }^{1}$ Cross-section & $\begin{array}{c}\text { Section } \\
\text { Reference } \\
\text { Distance } \\
\text { (SRD) in feet }\end{array}$ & $\begin{array}{c}{ }^{2} \text { Cross-section } \\
\text { development }\end{array}$ & Comments \\
\hline EXITX & -62 & 1 & Exit section \\
\hline FULLV & 0 & 2 & $\begin{array}{l}\text { Downstream Full-valley } \\
\text { section (Templated from } \\
\text { EXITX) }\end{array}$ \\
\hline BRIDG & 0 & 1 & Bridge section \\
\hline RDWAY & 10 & 1 & Road Grade section \\
\hline APPRO & 48 & 2 & $\begin{array}{l}\text { Modelled Approach sec- } \\
\text { tion (Templated from } \\
\text { ATEMP) }\end{array}$ \\
\hline ATEMP & 107 & 1 & $\begin{array}{l}\text { Approach section as sur- } \\
\text { veyed (Used as a tem- } \\
\text { plate) }\end{array}$ \\
\hline
\end{tabular}

${ }^{1}$ For location of cross-sections see plan-view sketch included with Level I field form, Appendix E.

For more detail on how cross-sections were developed see WSPRO input file. 


\section{Data and Assumptions Used in WSPRO Model}

Hydraulic analyses of the reach were done by use of the Federal Highway Administration's WSPRO step-backwater computer program (Shearman and others, 1986, and Shearman, 1990). The analyses reported herein reflect conditions existing at the site at the time of the study. Furthermore, in the development of the model it was necessary to assume no accumulation of debris or ice at the site. Results of the hydraulic model are presented in the Bridge Hydraulic Summary, Appendix B, and figure 7.

Channel roughness factors (Manning's " $n$ ") used in the hydraulic model were estimated using field inspections at each cross section following the general guidelines described by Arcement and Schneider (1989). Final adjustments to the values were made during the modelling of the reach. Channel " $\mathrm{n}$ " values for the reach ranged from 0.035 to 0.064 , and overbank "n" values ranged from 0.045 to 0.05 .

Normal depth at the exit section (EXITX) was assumed as the starting water surface. This depth was computed by use of the slope-conveyance method outlined in the user's manual for WSPRO (Shearman, 1990). The slope used was $0.0305 \mathrm{ft} / \mathrm{ft}$ which was determined from thalweg points downstream of the bridge.

The surveyed approach section (ATEMP) was moved along the approach channel slope $(0.035 \mathrm{ft} / \mathrm{ft})$ to establish the modelled approach section (APPRO), one bridge length upstream of the upstream face as recommended by Shearman and others (1986). This approach also provides a consistent method for determining scour variables.

For the 100-year and incipient-overtopping discharge, WSPRO assumes critical depth at the bridge section. Supercritical models were developed for these discharges. Analyzing both the supercritical and subcritical profiles for each discharge, it can be determined that the water surface profile does pass through critical depth within the bridge opening. Thus, the assumptions of critical depth at the bridge are satisfactory solutions. 


\section{Bridge Hydraulics Summary}

$\begin{array}{lll}\text { Average bridge embankment elevation } & 501.0 \\ \text { Average low steel elevation } & 498.9 & \boldsymbol{f t}\end{array}$

100-year discharge $\quad 2,350 \quad \mathrm{ft}^{3} / \mathrm{s}$

Water-surface elevation in bridge opening $\quad 494.2 \quad f t$

Road overtopping? ___ No Discharge over road __

\begin{tabular}{lcc} 
Area of flow in bridge opening & $168 \quad \boldsymbol{f t}^{2}$ \\
\cline { 2 - 3 } Average velocity in bridge opening & $14.0 \quad \mathrm{ft} / \mathrm{s}$
\end{tabular}

Maximum WSPRO tube velocity at bridge $\quad 17.1 \mathrm{ft} / \mathrm{s}$

Water-surface elevation at Approach section with bridge 497.5

Water-surface elevation at Approach section without bridge $\quad \overline{496.0}$

Amount of backwater caused by bridge

1.5 it

500-year discharge $\quad 3,050 \quad \mathrm{ft}^{3} / \mathrm{s}$

Water-surface elevation in bridge opening $\quad 499.0 \mathrm{ft}$

Road overtopping? ___ Yes Discharge over road _ $378 \quad \ldots$

Area of flow in bridge opening $\quad 288 \quad \mathrm{ft}^{2}$

Average velocity in bridge opening $\quad 9.3 \mathrm{ft} / \mathrm{s}$

Maximum WSPRO tube velocity at bridge 13.3 , s

Water-surface elevation at Approach section with bridge 500.8

Water-surface elevation at Approach section without bridge $\quad 496.9$

Amount of backwater caused by bridge 3.9 .

Incipient overtopping discharge $\quad 2,970 \mathrm{ft}^{3} / \mathrm{s}$

Water-surface elevation in bridge opening $495.5 \quad t$

Area of flow in bridge opening $\quad 197 \quad \mathrm{ft}^{2}$

Average velocity in bridge opening $\quad 15.1 \mathrm{ft} / \mathrm{s}$

Maximum WSPRO tube velocity at bridge $\quad 18.7 \mathrm{ft} / \mathrm{s}$

Water-surface elevation at Approach section with bridge

Water-surface elevation at Approach section without bridge

499.0

Amount of backwater caused by bridge $\quad 2.2$, $t$ 


\section{Scour Analysis Summary}

\section{Special Conditions or Assumptions Made in Scour Analysis}

Scour depths were computed using the general guidelines described in Hydraulic Engineering Circular 18 (Richardson and others, 1995). Scour depths were calculated assuming an infinite depth of erosive material and a homogeneous particle-size distribution. The results of the scour analysis are presented in tables 1 and 2 and a graph of the scour depths is presented in figure 8 .

Contraction scour was computed by use of Laursen's clear-water contraction scour equation (Richardson and others, 1995, p. 32, equation 20) for the 100-year and incipient road overtopping discharge. The 500-year discharge resulted in unsubmerged orifice flow. Contraction scour at bridges with orifice flow is best estimated by use of the Chang pressureflow scour equation (oral communication, J. Sterling Jones, October 4, 1996 and Richarson and others, 1995, p. 145-146). The results of Laursen's clear-water contraction scour for the 500 -year event were also computed and can be found in appendix F. In this case, the incipient road-overflow model resulted in the worst case contraction scour with a scour depth of $2.9 \mathrm{ft}$. The incipient road-overflow model also resulted in the worst case total scour with a depth at 19.8 at the right abutment.

Abutment scour was computed by use of the Froehlich equation (Richardson and others, 1995, p. 48, equation 28). Variables for the Froehlich equation include the Froude number of the flow approaching the embankments, the length of the embankment blocking flow, and the depth of flow approaching the embankment less any roadway overtopping. 


\section{Scour Results}

100-yr discharge 500-yr discharge

Contraction scour:

(Scour depths in feet)

Main channel
Live-bed scour
Clear-water scour
Depth to armoring

Left overbank

Right overbank

\section{Local scour:}

Abutment scour

\section{Left abutment}

Right abutment

Pier scour

Pier 1

Pier 2

Pier 3

Abutments:

\section{Left abutment}

\section{Right abutment}

Piers:

Pier 1

Pier 2

Incipient overtopping discharge 


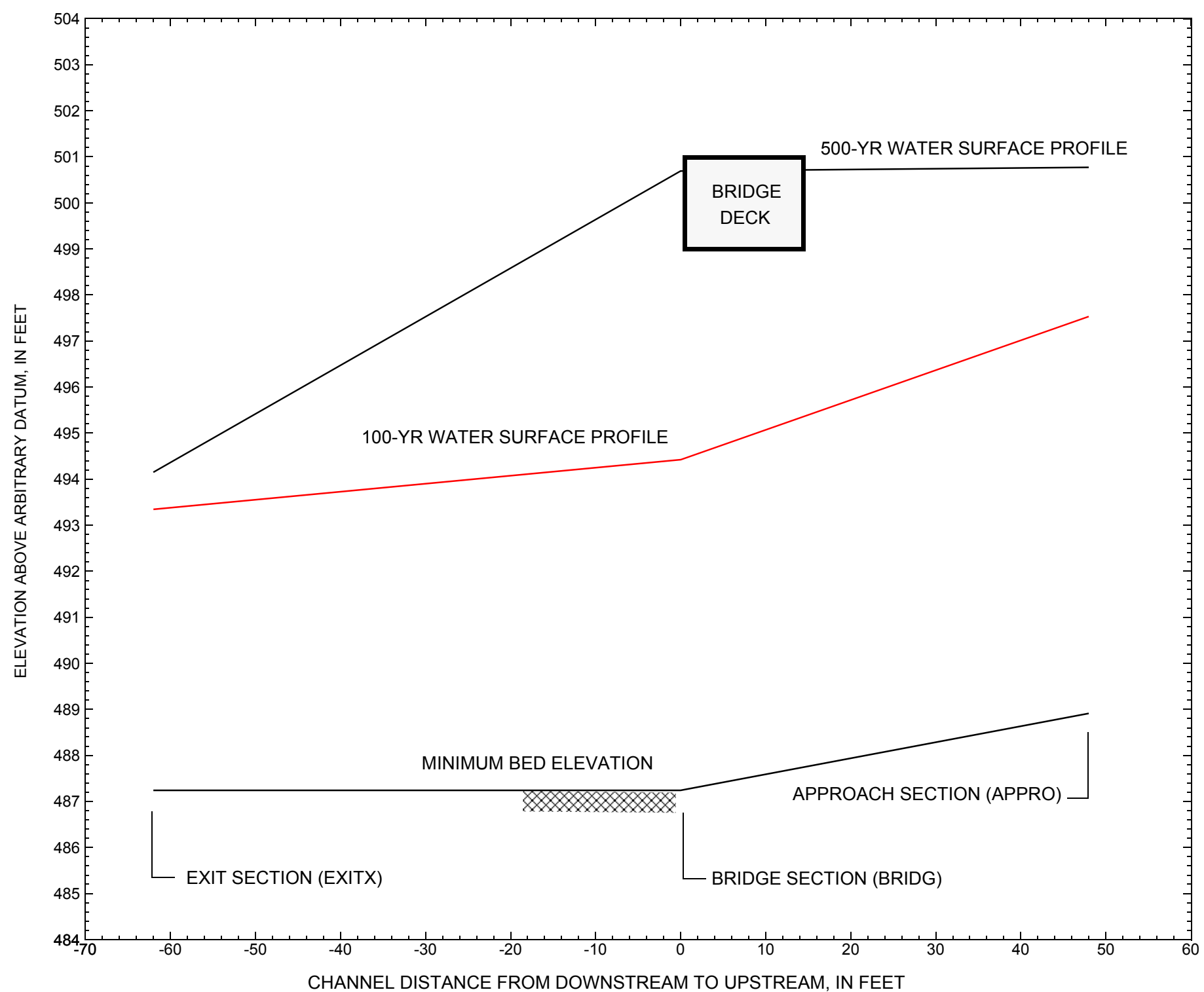

Figure 7. Water-surface profiles for the 100- and 500-yr discharges at structure BRNATH00290034 on Town Highway 34, crossing Locust Creek, Barnard, Vermont. 


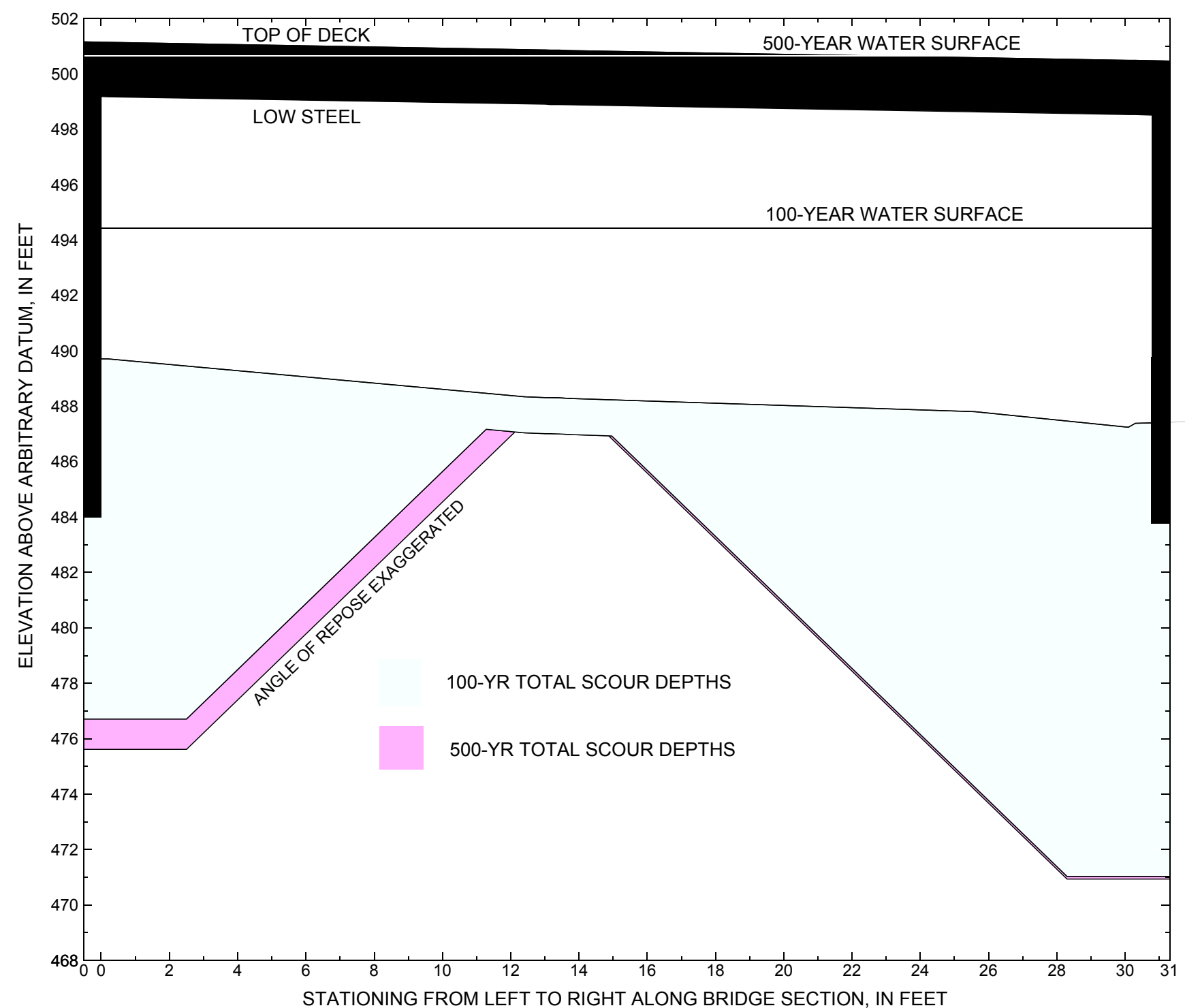

Figure 8. Scour elevations for the 100-yr and 500-yr discharges at structure BRNATH00290034 on Town Highway 29, crossing Locust Creek, Barnard, Vermont. 
Table 1. Remaining footing/pile depth at abutments for the 100-year discharge at structure BRNATH00290034 on Town Highway 29, crossing Locust Creek, Barnard, Vermont.

[VTAOT, Vermont Agency of Transportation; --,no data]

\begin{tabular}{|c|c|c|c|c|c|c|c|c|c|c|c|}
\hline Description & Station $^{1}$ & $\begin{array}{l}\text { VTAOT } \\
\text { minimum } \\
\text { low-chord } \\
\text { elevation } \\
\text { (feet) }\end{array}$ & $\begin{array}{l}\text { Surveyed } \\
\text { minimum } \\
\text { low-chord } \\
\text { elevation } \\
\quad \text { (feet) }\end{array}$ & $\begin{array}{c}\text { Bottom of } \\
\text { footing } \\
\text { elevation }{ }^{2} \\
\text { (feet) }\end{array}$ & $\begin{array}{c}\text { Channel } \\
\text { elevation at } \\
\text { abutment/ } \\
\text { pier }^{2} \\
\text { (feet) }\end{array}$ & $\begin{array}{l}\text { Contraction } \\
\text { scour depth } \\
\text { (feet) }\end{array}$ & $\begin{array}{l}\text { Abutment } \\
\text { scour } \\
\text { depth } \\
\text { (feet) }\end{array}$ & $\begin{array}{l}\text { Pier } \\
\text { scour } \\
\text { depth } \\
\text { (feet) }\end{array}$ & $\begin{array}{l}\text { Depth of } \\
\text { total scour } \\
\text { (feet) }\end{array}$ & $\begin{array}{c}\text { Elevation of } \\
\text { scour }^{2} \\
\text { (feet) }\end{array}$ & $\begin{array}{c}\text { Remaining } \\
\text { footing/pile } \\
\text { depth } \\
\text { (feet) }\end{array}$ \\
\hline \multicolumn{12}{|c|}{100 -yr. discharge is 2,350 cubic-feet per second } \\
\hline Left abutment & 0.0 & 496.5 & 499.5 & 484 & 489.7 & 1.3 & 11.7 & -- & 13.0 & 476.7 & -7 \\
\hline Right abutment & 30.8 & 495.2 & 498.2 & 484 & 487.4 & 1.3 & 15.1 & -- & 16.4 & 471.0 & -13 \\
\hline
\end{tabular}

1.Measured along the face of the most constricting side of the bridge.

2.Arbitrary datum for this study.

Table 2. Remaining footing/pile depth at abutments for the 500-year discharge at structure BRNATH00290034 on Town Highway 29, crossing Locust Creek, Barnard, Vermont.

[VTAOT, Vermont Agency of Transportation; --, no data]

\begin{tabular}{|c|c|c|c|c|c|c|c|c|c|c|c|}
\hline Description & Station $^{1}$ & $\begin{array}{l}\text { VTAOT } \\
\text { minimum } \\
\text { low-chord } \\
\text { elevation } \\
\text { (feet) }\end{array}$ & $\begin{array}{l}\text { Surveyed } \\
\text { minimum } \\
\text { low-chord } \\
\text { elevation }{ }^{2} \\
\text { (feet) }\end{array}$ & $\begin{array}{c}\text { Bottom of } \\
\text { footing } \\
\text { elevation } \\
\text { (feet) }\end{array}$ & $\begin{array}{c}\text { Channel } \\
\text { elevation at } \\
\text { abutment/ } \\
\text { pier }^{2} \\
\text { (feet) }\end{array}$ & $\begin{array}{l}\text { Contraction } \\
\text { scour depth } \\
\text { (feet) }\end{array}$ & $\begin{array}{l}\text { Abutment } \\
\text { scour } \\
\text { depth } \\
\text { (feet) }\end{array}$ & $\begin{array}{l}\text { Pier } \\
\text { scour } \\
\text { depth } \\
\text { (feet) }\end{array}$ & $\begin{array}{l}\text { Depth of } \\
\text { total scour } \\
\text { (feet) }\end{array}$ & $\begin{array}{c}\text { Elevation of } \\
\text { scour }^{2} \\
\text { (feet) }\end{array}$ & $\begin{array}{c}\text { Remaining } \\
\text { footing/pile } \\
\text { depth } \\
\text { (feet) }\end{array}$ \\
\hline \multicolumn{12}{|c|}{500 -yr. discharge is 3,050 cubic-feet per second } \\
\hline Left abutment & 0.0 & 496.5 & 499.5 & 484 & 489.7 & 0.0 & 14.1 & -- & 14.1 & 475.6 & -8 \\
\hline Right abutment & 30.8 & 495.2 & 498.2 & 484 & 487.4 & 0.0 & 16.5 & -- & 16.5 & 470.9 & -13 \\
\hline
\end{tabular}

1.Measured along the face of the most constricting side of the bridge.

2.Arbitrary datum for this study. 


\section{SELECTED REFERENCES}

Arcement, G.J., Jr., and Schneider, V.R., 1989, Guide for selecting Manning's roughness coefficients for natural channels and flood plains: U.S. Geological Survey Water-Supply Paper 2339, 38 p.

Barnes, H.H., Jr., 1967, Roughness characteristics of natural channels: U.S. Geological Survey Water-Supply Paper 1849,213 p.

Benson, M. A., 1962, Factors Influencing the Occurrence of Floods in a Humid Region of Diverse Terrain: U.S. Geological Survey WaterSupply Paper 1580-B, 64 p.

Brown, S.A. and Clyde, E.S., 1989, Design of riprap revetment: Federal Highway Administration Hydraulic Engineering Circular No. 11, Publication FHWA-IP-89-016, 156 p.

Federal Highway Administration, 1983, Runoff estimates for small watersheds and development of sound design: Federal Highway Administration Report FHWA-RD-77-158

Federal Emergency Management Agency, 1980, Flood Insurance Study, Town of Barnard, Windsor County, Vermont: Washington, D.C., January 1980.

Froehlich, D.C., 1989, Local scour at bridge abutments in Ports, M.A., ed., Hydraulic Engineering--Proceedings of the 1989 National Conference on Hydraulic Engineering: New York, American Society of Civil Engineers, p. 13-18.

Hayes, D.C.,1993, Site selection and collection of bridge-scour data in Delaware, Maryland, and Virginia: U.S. Geological Survey WaterResources Investigation Report 93-4017, 23 p.

Johnson, C.G. and Tasker, G.D.,1974, Progress report on flood magnitude and frequency of Vermont streams: U.S. Geological Survey OpenFile Report 74-130, 37 p.

Lagasse, P.F., Schall, J.D., Johnson, F., Richardson, E.V., Chang, F., 1995, Stream Stability at Highway Structures: Federal Highway Administration Hydraulic Engineering Circular No. 20, Publication FHWA-IP-90-014, 144 p.

Laursen, E.M., 1960, Scour at bridge crossings: Journal of the Hydraulics Division, American Society of Civil Engineers, v. 86, no. HY2, p. 39-53.

Potter, W. D., 1957a, Peak rates of runoff in the Adirondack, White Mountains, and Maine woods area, Bureau of Public Roads

Potter, W. D., 1957b, Peak rates of runoff in the New England Hill and Lowland area, Bureau of Public Roads

Richardson, E.V. and Davis, S.R., 1995, Evaluating scour at bridges: Federal Highway Administration Hydraulic Engineering Circular No. 18, Publication FHWA-IP-90-017, 204 p.

Richardson, E.V., Simons, D.B., and Julien, P.Y., 1990, Highways in the river environment: Federal Highway Administration Publication FHWA-HI-90-016.

Ritter, D.F., 1984, Process Geomorphology: W.C. Brown Co., Debuque, Iowa, 603 p.

Shearman, J.O., 1990, User's manual for WSPRO--a computer model for water surface profile computations: Federal Highway Administration Publication FHWA-IP-89-027, 187 p.

Shearman, J.O., Kirby, W.H., Schneider, V.R., and Flippo, H.N., 1986, Bridge waterways analysis model; research report: Federal Highway Administration Publication FHWA-RD-86-108, 112 p.

Talbot, A.N., 1887, The determination of water-way for bridges and culverts.

U.S. Department of Transportation, 1993, Stream stability and scour at highway bridges, Participant Workbook: Federal Highway Administration Publication FHWA HI-91-011.

U.S. Geological Survey, 1980, Bethel, Vermont 7.5 Minute Series quadrangle map: U.S. Geological Survey Topographic Maps, Photoinspected 1983, Scale 1:24,000. 


\section{APPENDIX A: \\ WSPRO INPUT FILE}




\section{WSPRO INPUT FILE}

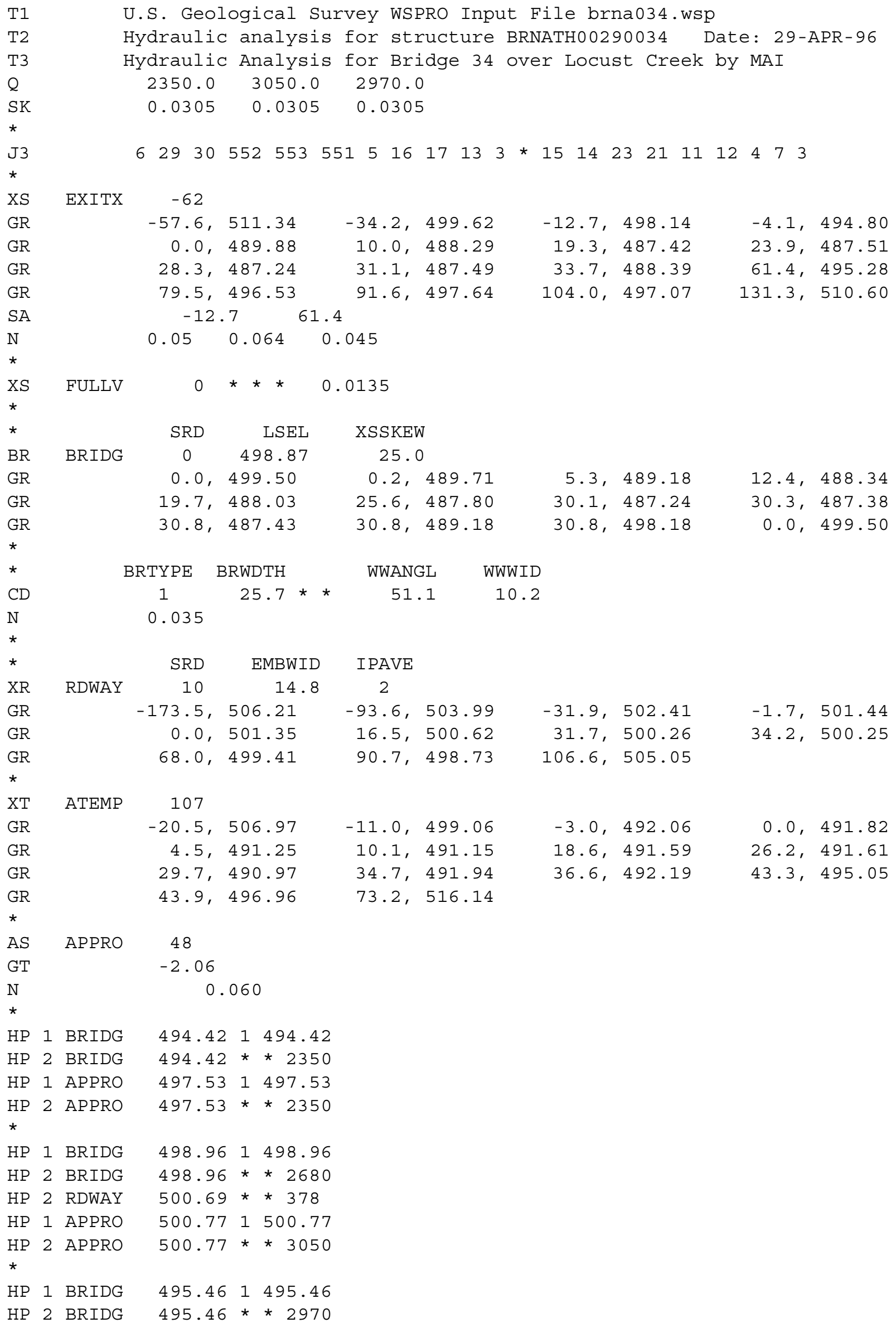




\section{APPENDIX B: \\ WSPRO OUTPUT FILE}


WSPRO OUTPUT FILE

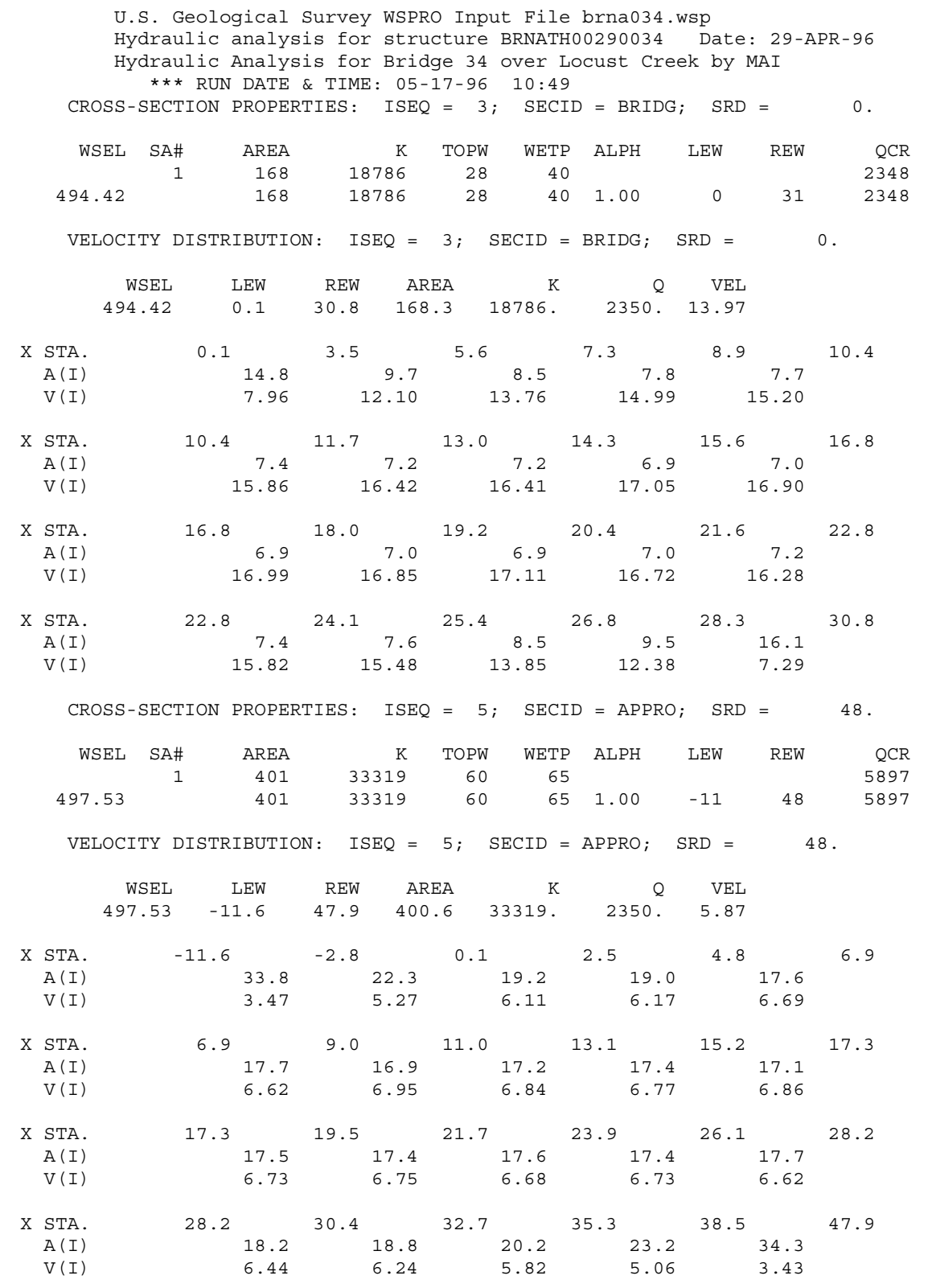


WSPRO OUTPUT FILE (continued)

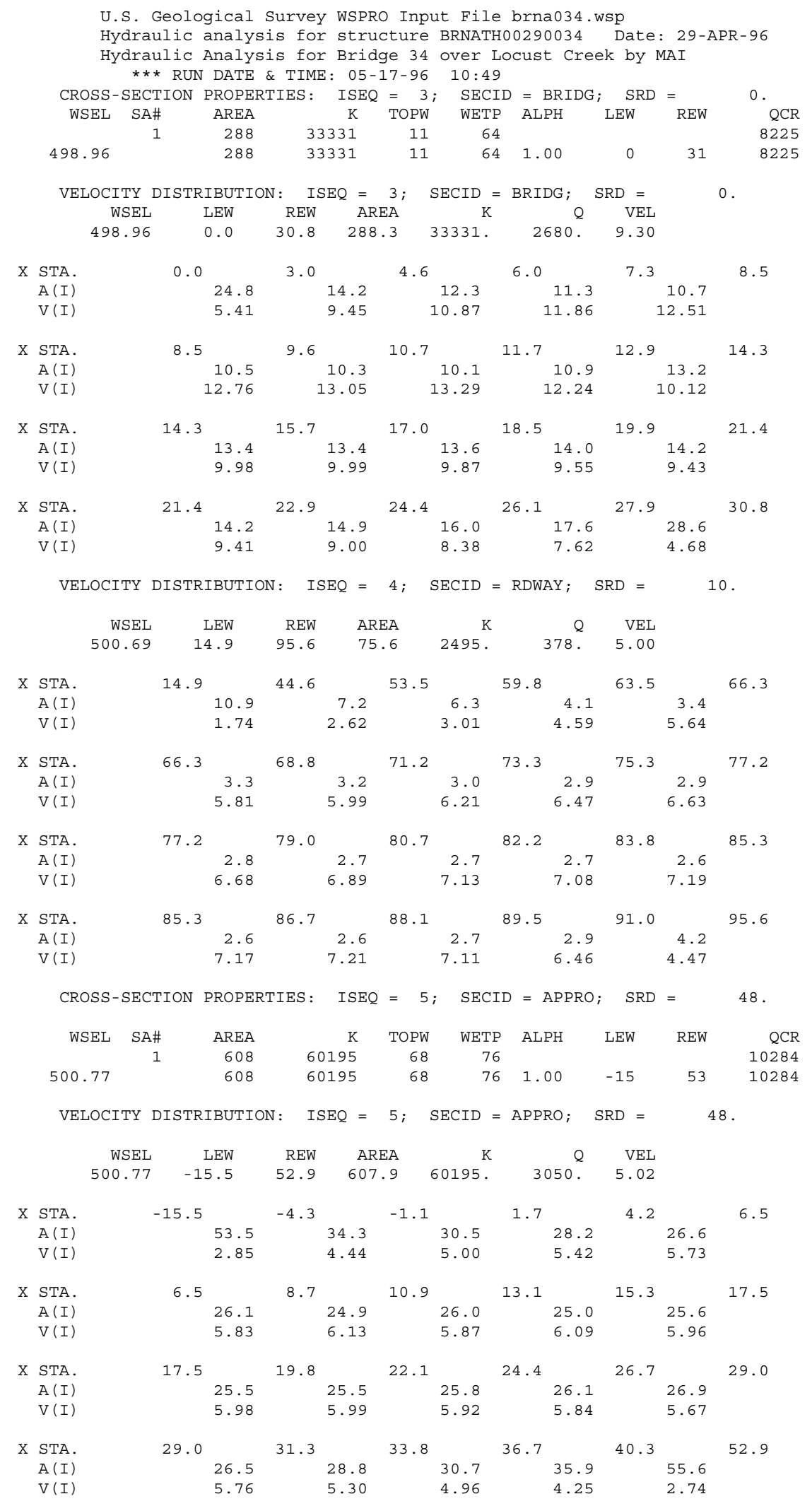


WSPRO OUTPUT FILE (continued)

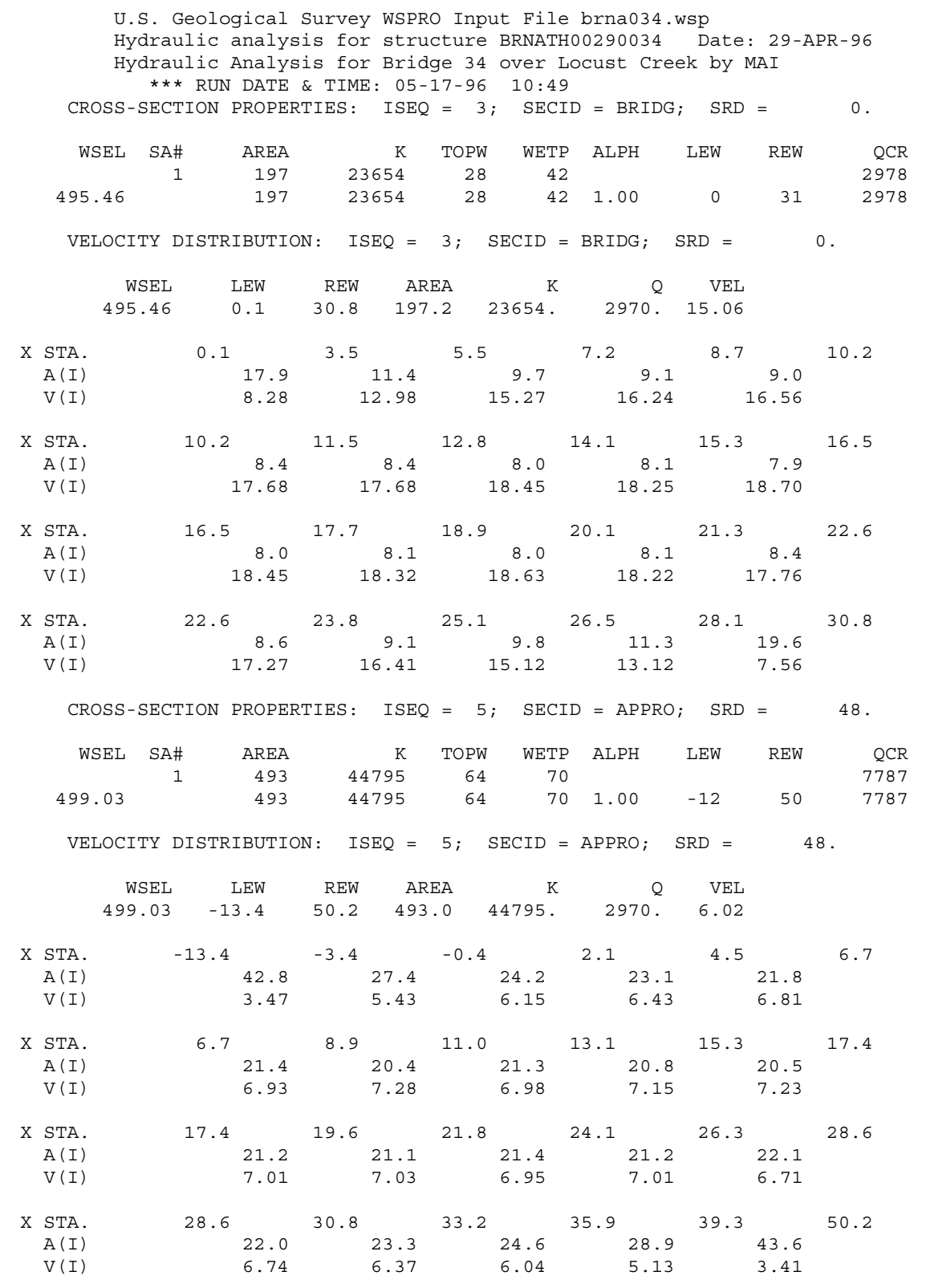


WSPRO OUTPUT FILE (continued)

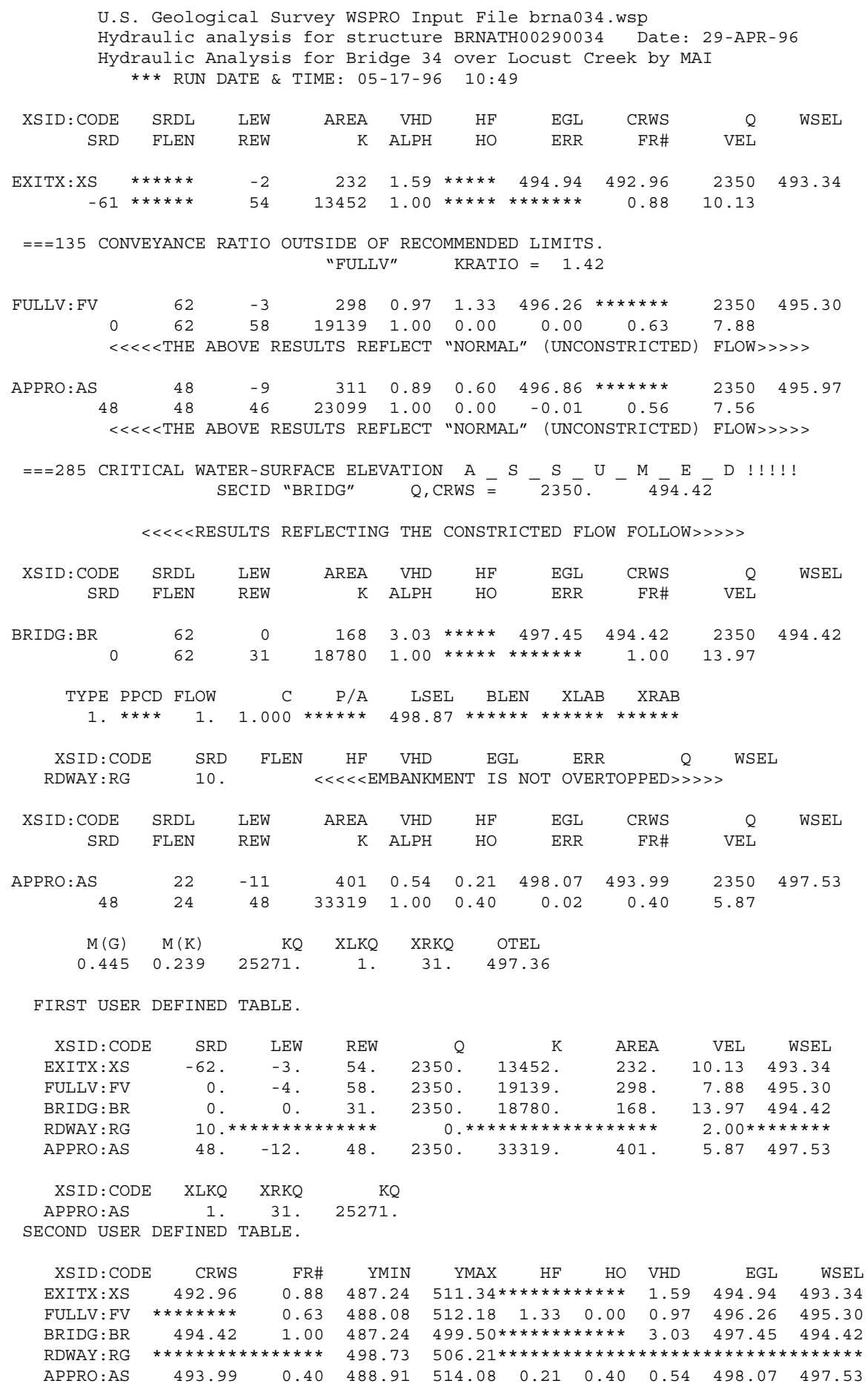


WSPRO OUTPUT FILE (continued)

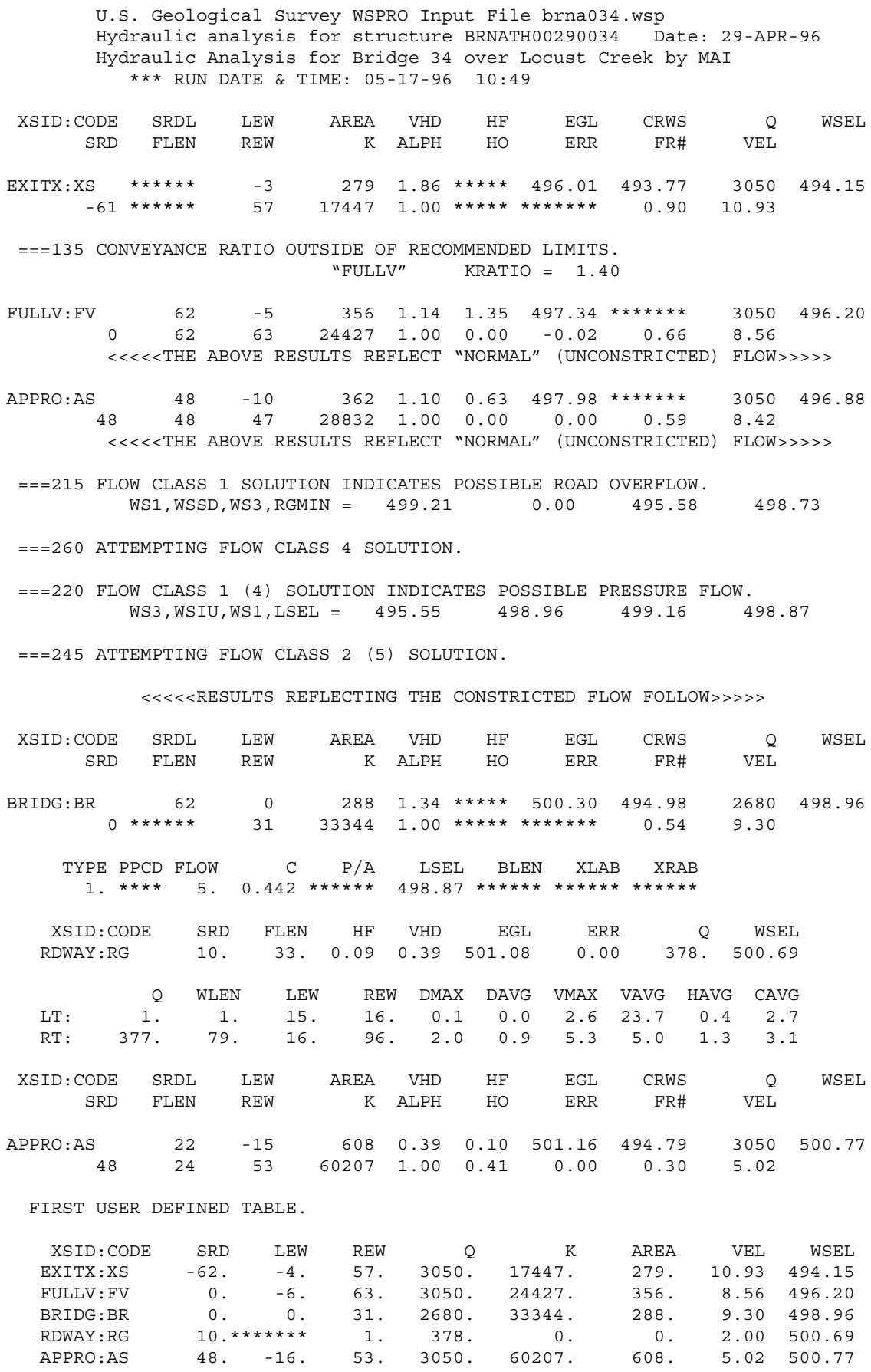

SECOND USER DEFINED TABLE.

$\begin{array}{ccrrrrrrrr}\text { XSID : CODE } & \text { CRWS } & \text { FR\# } & \text { YMIN } & \text { YMAX } & \text { HF } & \text { HO } & \text { VHD } & \text { EGL } & \text { WSEL } \\ \text { EXITX:XS } & 493.77 & 0.90 & 487.24 & 511.34 * * * * * * * * * * & 1.86 & 496.01 & 494.15 \\ \text { FULLV:FV } & * * * * * * * * & 0.66 & 488.08 & 512.18 & 1.35 & 0.00 & 1.14 & 497.34 & 496.20 \\ \text { BRIDG : BR } & 494.98 & 0.54 & 487.24 & 499.50 * * * * * * * * * * & 1.34 & 500.30 & 498.96 \\ \text { RDWAY:RG } & * * * * * * * * * * * * * * * & 498.73 & 506.21 & 0.09 * * * * * * & 0.39 & 501.08 & 500.69 \\ \text { APPRO:AS } & 494.79 & 0.30 & 488.91 & 514.08 & 0.10 & 0.41 & 0.39 & 501.16 & 500.77\end{array}$


WSPRO OUTPUT FILE (continued)

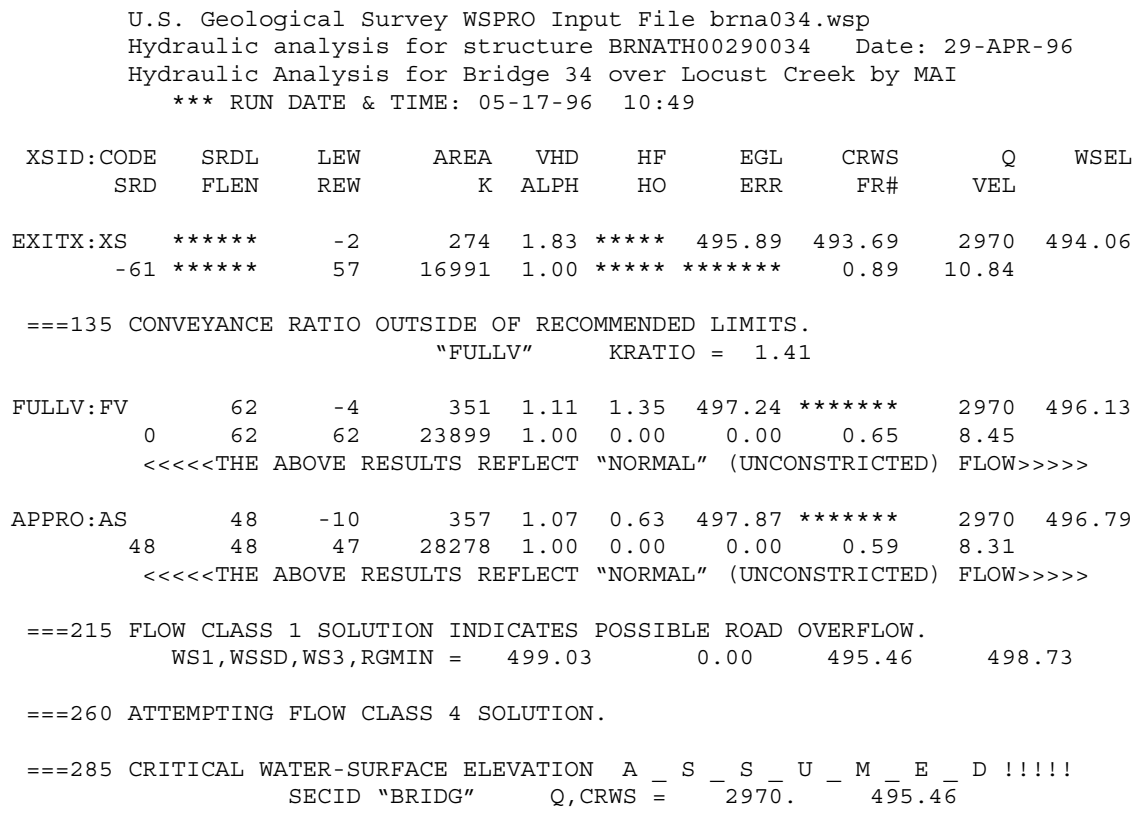




\section{APPENDIX C:}

\section{BED-MATERIAL PARTICAL-SIZE DISTRIBUTION}




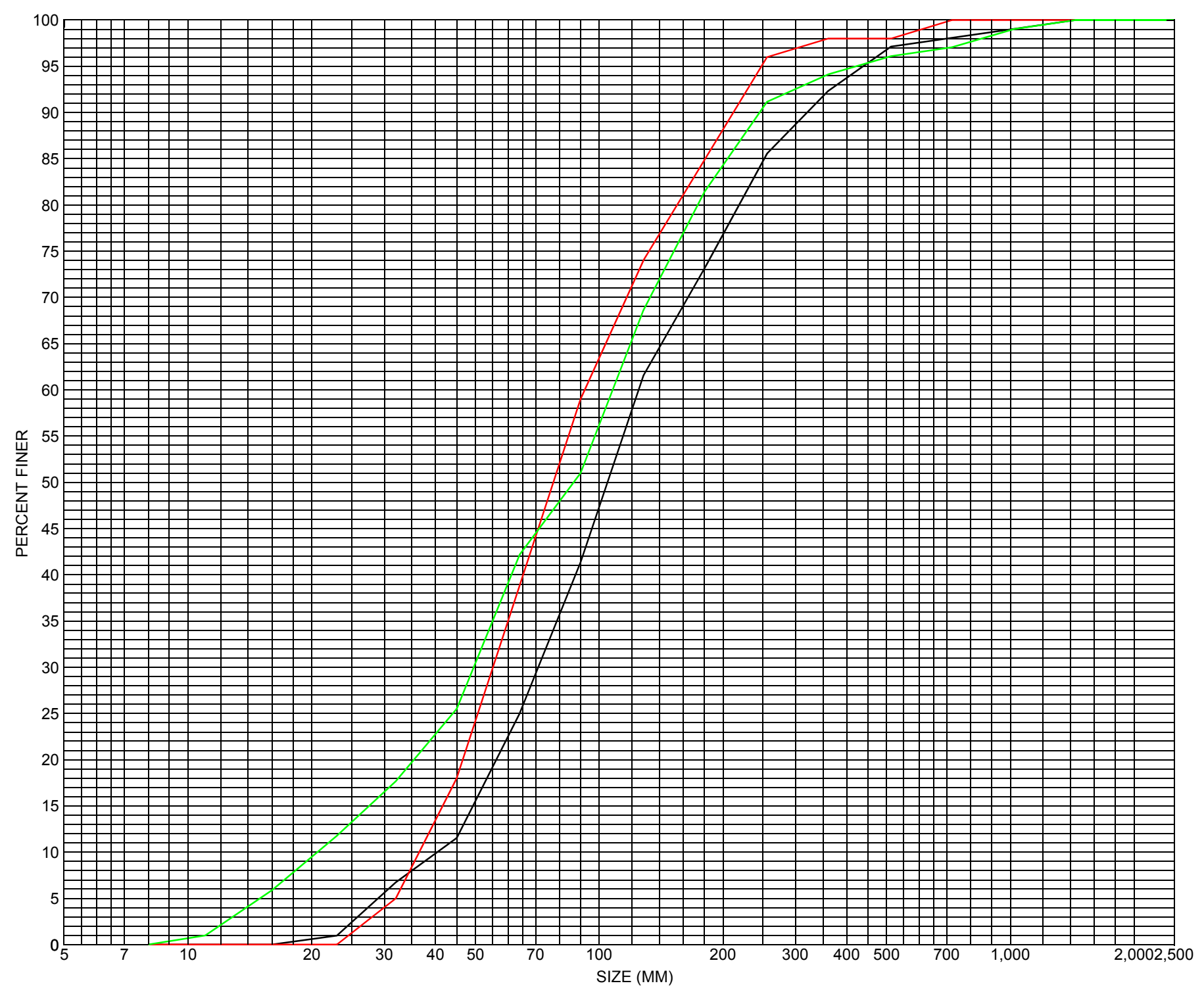

Appendix C. Bed material particle-size distribution for three pebble count transects near the channel approach section of structure BRNATH00290034, in Barnard, Vermont. 


\section{APPENDIX D: \\ HISTORICAL DATA FORM}




\section{Structure Number BRNATH00290034}

\section{General Location Descriptive}

Data collected by (First Initial, Full last name) M. IVANOFF

Date $(M M / D D / Y Y) \_\mathbf{0 8} / \underline{\mathbf{2 3}} / \underline{\mathbf{9 4}}$

Highway District Number (I - 2; nn) 04

Town (FIPS place code; I - 4; nnnnn) $\mathbf{0 2 7 2 5}$

Waterway (I - 6) LOCUST CREEK

Route Number TH029

Topographic Map Bethel

Latitude (I - 16; nnnn.n) $\mathbf{4 3 4 5 3}$
County (FIPS county code; I - 3; nnn)

Mile marker (I - 11; nnn.nnn) $\mathbf{0 0 0 0 0 0}$

Road Name (I - 7): -

Vicinity (I - 9) 0.3 MI TO JCT W VT12

Hydrologic Unit Code: $\mathbf{0 1 0 8 0 1 0 5}$

Longitude (i - 17; nnnnn.n) $\mathbf{7 2 3 8 1}$

\section{Select Federal Inventory Codes}

FHWA Structure Number (I - 8) 10140300341403

Maintenance responsibility $(I-21 ; n n) \quad \mathbf{0 3} \quad$ Maximum span length $(I-48 ; n n n n) \underline{\mathbf{0 0 3 2}}$

Year built (I - 27; YYYY) 1974

Structure length (I - 49; nnnnnn) $\underline{\mathbf{0 0 0 0 3 7}}$

Average daily traffic, ADT (I - 29; nnnnnn) 000050 Deck Width (I - 52; nn.n) 148

Year of ADT (I - 30; YY) $\mathbf{9 0}$

Channel \& Protection $(I-61 ; n) \underline{7}$

Opening skew to Roadway $(I-34 ; n n) \quad 19$

Waterway adequacy $(I-71 ; n) \underline{7}$

Operational status $(I-41 ; X) \mathbf{A}$

Underwater Inspection Frequency $(I-92 B ; X Y Y) \_\mathbf{N}$

Structure type (I - 43; nnn) 101

Year Reconstructed (I - 106) $\mathbf{0 0 0 0}$

Approach span structure type (I - 44; nnn) $\mathbf{0 0 0}$

Clear span (nnn.n ft)

Number of spans (I - 45; nnn) $\underline{\mathbf{0 0 1}}$

Vertical clearance from streambed (nnn.n ft) $\underline{\mathbf{0 0 8 . 0}}$

Number of approach spans (I- 46; nnnn) $\underline{\mathbf{0 0 0 0}}$ Waterway of full opening $\left(n n n . n \mathrm{ft}^{2}\right) \underline{\mathbf{2 4 0 . 0}}$

Comments:

Structural inspection report of 5/25/94 indicates that the abutment concrete is in "like new" condition. The upstream left wingwall is indicated as having cracks. No undermining or settlement are reported. Report noted minor channel scour and slight exposure at downstream end of the right abutment. Very minor embankment erosion is reported. No noted debris or channel bars. Channel makes a slight turn into the bridge crossing. Stone fill is reported in fair condition. 


\section{Bridge Hydrologic Data}

Is there hydrologic data available? $\underline{\mathbf{Y}}$ if No, type ctrl- $n$ h VTAOT Drainage area $\left(m i^{2}\right): \underline{11.6}$

Terrain character: Mountainous

Stream character \& type: -

Streambed material: Stone and gravel with some moderate size boulders.

Discharge Data (cfs): $\quad \mathrm{Q}_{2.33}-$

$\mathrm{Q}_{50} \mathbf{2 0 0 0}$

Record flood date $(M M / D D / Y Y)$ : - $1-1-$

$\begin{array}{lll}Q_{10} & \mathbf{1 2 0 0} & Q_{25} 1650 \\ Q_{100} & \mathbf{2 3 5 0} & Q_{500}-\end{array}$

Water surface elevation $(f t):-$

Estimated Discharge (cfs): Velocity at $\mathrm{Q} \mathbf{2 5}$ $(\mathrm{ft} / \mathrm{s}): \mathbf{1 1 . 5}$

Ice conditions (Heavy, Moderate, Light) : Debris (Heavy, Moderate, Light):

The stage increases to maximum highwater elevation (Rapidly, Not rapidly):

The stream response is (Flashy, Not flashy):

Describe any significant site conditions upstream or downstream that may influence the stream's stage: -

Watershed storage area (in percent):

The watershed storage area is: - _ (1-mainly at the headwaters; 2- uniformly distributed; 3-immediatly upstream oi the site)

Water Surface Elevation Estimates for Existing Structure:

\begin{tabular}{|l|l|l|l|l|l|}
\hline Peak discharge frequency & $Q_{2.33}$ & $Q_{10}$ & $Q_{25}$ & $Q_{50}$ & $Q_{100}$ \\
Water surface elevation (ft) $)$ & - & - & $\mathbf{7 . 0}$ & $\mathbf{8 . 1}$ & $\mathbf{9 . 1}$ \\
Velocity $(\mathrm{ft} / \mathrm{sec})$ & - & - & $\mathbf{1 1 . 5}$ & - & - \\
\hline
\end{tabular}

Long term stream bed changes: -

Is the roadway overtopped below the $\mathrm{Q}_{100}$ ? (Yes, No, Unknown): $\mathbf{U}$ Frequency: Relief Elevation $(f t)$ :

Discharge over roadway at $Q_{100}\left(f t^{3} / \mathrm{sec}\right)$ :

Are there other structures nearby? (Yes, No, Unknown): $\mathbf{Y}$ Upstream distance (miles): Town: If No or Unknown, type ctrl-n os Highway No. : Structure No. : 26 Year Built:

Clear span (ft): Clear Height (ft): Full Waterway $\left(f t^{2}\right)$ : 
Downstream distance (miles): Town: Barnard Year Built:

Highway No. : Structure No. : 25

Clear span (ft): Clear Height (ft): Structure Type: Bridge

Comments:

\section{USGS Watershed Data}

Watershed Hydrographic Data

Drainage area $(D A) \quad 11.48 \quad \mathrm{mi}^{2}$

Watershed storage (ST) 0.2

Bridge site elevation 920 $\mathrm{ft}$ $\%$

Main channel length 7.34 mi

$10 \%$ channel length elevation $\mathrm{ft} \quad 85 \%$ channel length elevation $\mathrm{ft}$

Main channel slope $(S)$

(S) 172.57 $\mathrm{ft} / \mathrm{mi}$

Watershed Precipitation Data

Average site precipitation in Average headwater precipitation in

Maximum 2yr-24hr precipitation event $(124,2)$ in

Average seasonal snowfall (Sn) $\mathrm{ft}$ 


\section{Bridge Plan Data}

Are plans available? $\underline{Y}$ If no, type ctrl-n pl Date issued for construction (MM/YYYY): 05 / 1974 Project Number DSR 4B-13 Minimum channel bed elevation: 4 85.0 Low superstructure elevation: USLAB $\underline{496.15}$ DSLAB $\underline{496.15}$ USRAB $\underline{495.04}$ DSRAB $\underline{495.04}$ Benchmark location description:

BM\#1, spike in a 4 inch maple, 18 feet from right bank road approach (side of roadway is not clear), elevation 500.00 feet.

Reference Point (MSL, Arbitrary, Other): Arbitrary $\quad$ Datum (NAD27, NAD83, Other): Arbitrary Foundation Type: 1 (1-Spreadfooting; 2-Pile; 3- Gravity; 4-Unknown)

If 1: Footing Thickness $\mathbf{2 . 0} \quad$ Footing bottom elevation: $\underline{\mathbf{4 8 1 . 0 0}}$

If 2: Pile Type:___ (1-Wood; 2-Steel or metal; 3-Concrete) Approximate pile driven length:

If 3: Footing bottom elevation:

Is boring information available? $\quad$ N If no, type ctrl-n bi Number of borings taken: _-

Foundation Material Type: $\mathbf{3}$ (1-regolith, 2-bedrock, 3-unknown)

Briefly describe material at foundation bottom elevation or around piles:

NO FOUNDATION MATERIAL INFORMATION

Comments:

Some hydraulic information is printed on the plans: $Q 10=1200, Q 25=1650$, high water $=7.0$ feet;

$Q 50=2000$, high water $=8.1$ feet,$Q 100=2350$, high water $=9.1$ feet, drainage area $=11.6$ square miles, outlet velocity at $Q 25=11.0$ feet $/$ second. 


\section{Cross-sectional Data}

Is cross-sectional data available? $\mathbf{N}$ If no, type ctrl-n xs

Source (FEMA, VTAOT, Other)? -

Comments: NO CROSS SECTION INFORMATION

\begin{tabular}{|l|l|l|l|l|l|l|l|l|l|l|l|}
\hline Station & - & - & - & - & - & - & - & - & - & - & - \\
\hline Feature & - & - & - & - & - & - & - & - & - & - & - \\
\hline $\begin{array}{l}\text { Low cord } \\
\text { elevation }\end{array}$ & - & - & - & - & - & - & - & - & - & - & - \\
\hline $\begin{array}{l}\text { Bed } \\
\text { elevation }\end{array}$ & - & - & - & - & - & - & - & - & - & - & - \\
\hline $\begin{array}{l}\text { Low cord to } \\
\text { bed length }\end{array}$ & - & - & - & - & - & - & - & - & - & - & - \\
\hline Station & - & - & - & - & - & - & - & - & - & - & - \\
\hline Feature & - & - & - & - & - & - & - & - & - & - & - \\
\hline $\begin{array}{l}\text { Low cord } \\
\text { elevation }\end{array}$ & - & - & - & - & - & - & - & - & - & - & - \\
\hline $\begin{array}{l}\text { Bed } \\
\text { elevation }\end{array}$ & - & - & - & - & - & - & - & - & - & - & - \\
\hline $\begin{array}{l}\text { Low cord to } \\
\text { bed length }\end{array}$ & - & - & - & - & - & - & - & - & - & - & - \\
\hline
\end{tabular}

Source (FEMA, VTAOT, Other)?

Comments: NO CROSS SECTION INFORMATION

\begin{tabular}{|l|l|l|l|l|l|l|l|l|l|l|l|}
\hline Station & - & - & - & - & - & - & - & - & - & - & - \\
\hline Feature & - & - & - & - & - & - & - & - & - & - & - \\
\hline $\begin{array}{l}\text { Low cord } \\
\text { elevation }\end{array}$ & - & - & - & - & - & - & - & - & - & - & - \\
\hline $\begin{array}{l}\text { Bed } \\
\text { elevation }\end{array}$ & - & - & - & - & - & - & - & - & - & - & - \\
\hline $\begin{array}{l}\text { Low cord to } \\
\text { bed length }\end{array}$ & - & - & - & - & - & - & - & - & - & - & - \\
\hline Station & - & - & - & - & - & - & - & - & - & - & - \\
\hline Feature & - & - & - & - & - & - & - & - & - & - & - \\
\hline $\begin{array}{l}\text { Low cord } \\
\text { elevation }\end{array}$ & - & - & - & - & - & - & - & - & - & - & - \\
\hline $\begin{array}{l}\text { Bed } \\
\text { elevation }\end{array}$ & - & - & - & - & - & - & - & - & - & - & - \\
\hline $\begin{array}{l}\text { Low cord to } \\
\text { bed length }\end{array}$ & - & - & - & - & - & - & - & - & - & - & - \\
\hline
\end{tabular}




\section{APPENDIX E: \\ LEVEL I DATA FORM}


U. S. Geological Survey

Bridge Field Data Collection and Processing Form

Qa/Qc Check by: Date:

\section{Structure Number}

BRNATH00290034

Computerized by: Date:

Reviewd by: Date:

\section{A. General Location Descriptive}

1. Data collected by (First Initial, Full last name) M. WEBER

2. Highway District Number 04

Mile marker 000000

County 027 (WINDSOR)

Town 02725 (BARNARD)

Waterway (l - 6) LOCUST CREEK

Route Number TH029

Road Name -

Hydrologic Unit Code: $\mathbf{0 1 0 8 0 1 0 5}$

3. Descriptive comments:

The bridge is located about 0.3 mile southwest of the intersection of town highway 29 with State Route 12.

Field checking and augmenting earlier Level I forms.

\section{B. Bridge Deck Observations}
4. Surface cover... LBUS 6
RBUS 6
LBDS 6
RBDS 5
Overall 6

(2b us, ds,lb,rb: 1- Urban; 2- Suburban; 3- Row crops; 4- Pasture; 5- Shrub- and brushland; 6- Forest; 7- Wetland)
5. Ambient water surface... US $\underline{2}$
UB 1
DS $\underline{2}$
(1- pool; 2- riffle)

6. Bridge structure type 1 (1- single span; 2- multiple span; 3- single arch; 4- multiple arch; 5-cylindrical culvert; 6- box culvert; or 7- other)

7. Bridge length $\underline{\mathbf{3 7}}$

(feet)

Span length $\underline{\mathbf{3 2}}$

(feet)

Bridge width 14.8 (feet)

\section{Road approach to bridge:}
8. LB 2 RB 1
( 0 even, 1- lower, 2- higher)
9. LB 2 RB 2
(1-Paved, 2- Not paved)

10. Embankment slope (run / rise in feet / foot)

US left $\quad-: 1$

US right $\quad-: 1$

\begin{tabular}{|c|c|c|c|c|}
\hline & \multicolumn{2}{|c|}{ Protection } & \multirow{2}{*}{ 13. Erosion } & \multirow{2}{*}{ 14.Severity } \\
\hline & 11.Type & 12.Cond. & & \\
\hline LBUS & 0 & - & 2 & 1 \\
\hline RBUS & $\mathbf{0}$ & - & 2 & 1 \\
\hline RBDS & $\mathbf{0}$ & - & $\mathbf{0}$ & - \\
\hline LBDS & $\mathbf{0}$ & - & 2 & 1 \\
\hline
\end{tabular}

Bank protection types: 0- none; 1- < 12 inches;

2- $<36$ inches; $3-<48$ inches;

4- < 60 inches; 5- wall / artificial levee

Bank protection conditions: 1- good; 2- slumped;

3- eroded; 4- failed

Erosion: 0 - none; 1- channel erosion; 2 -

road wash; 3- both; 4- other

Erosion Severity: 0 - none; 1- slight; 2- moderate; 3- severe

\section{Channel approach to bridge (BF):}

15. Angle of approach: 15

16. Bridge skew: 25

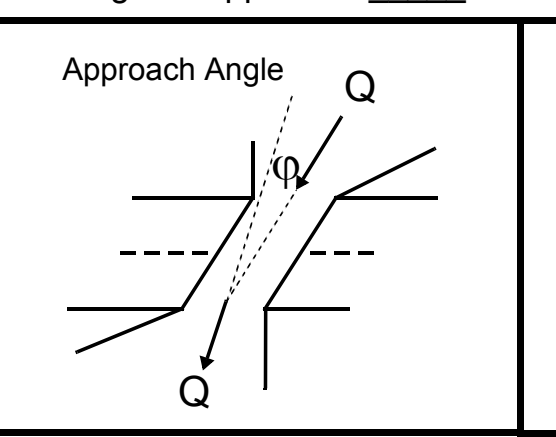

17. Channel impact zone 1:

Where? RB (LB, RB)

Exist? $\mathbf{Y}(Y$ or $N)$ Bridge Skew Angle

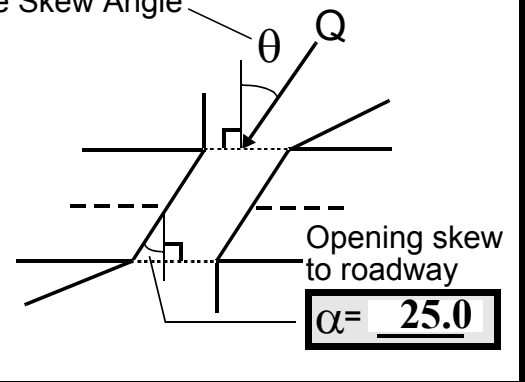

Range? 8 feet $\underline{\text { US }}$

Severity 1

Channel impact zone 2:

(US, UB, DS) to $\underline{\mathbf{1 0}}$ feet $\underline{\mathbf{D S}}$

Where? LB (LB, RB)

Exist? $\mathbf{Y}(Y$ or $N)$

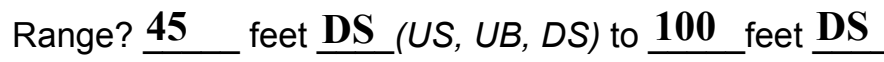

Impact Severity: 0- none to very slight; 1- Slight; 2- Moderate; 3- Severe 
18. Bridge Type: 1a

1a- Vertical abutments with wingwalls

1 b- Vertical abutments without wingwalls

2- Vertical abutments and wingwalls, sloping embankment Wingwalls perpendicular to abut. face

3- Spill through abutments

4- Sloping embankment, vertical wingwalls and abutments

Wingwall angle less than $90^{\circ}$.

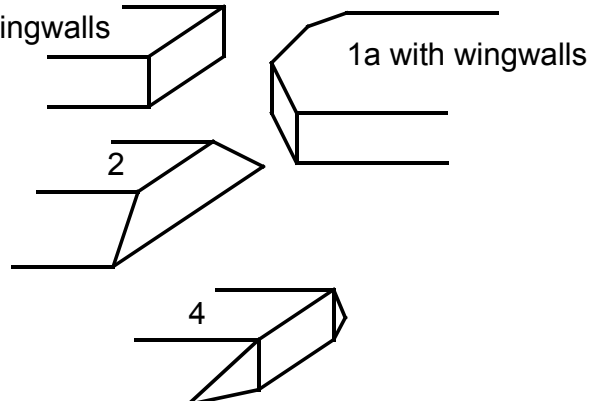

19. Bridge Deck Comments (surface cover variations, measured bridge and span lengths, bridge type variations, approach overflow width, etc.)

4. There is shrub and brushland near the bridge on the right bank downstream and gravel roadway bisects the area but forested beyond.

7. Values are from VTAOT database. Measured dimensions are: bridge length: $36.5 \mathrm{ft}$, span length: $32 \mathrm{ft}$, roadway width: $15 \mathrm{ft}$.

10. Road embankments cited as not significant on the Survey Log Notes.

11. There is no road approach protection apparent or detected using a rangepole to probe through snow on the road approaches. Old photos from previous assessments justify the no protection designation.

\section{Upstream Channel Assessment}

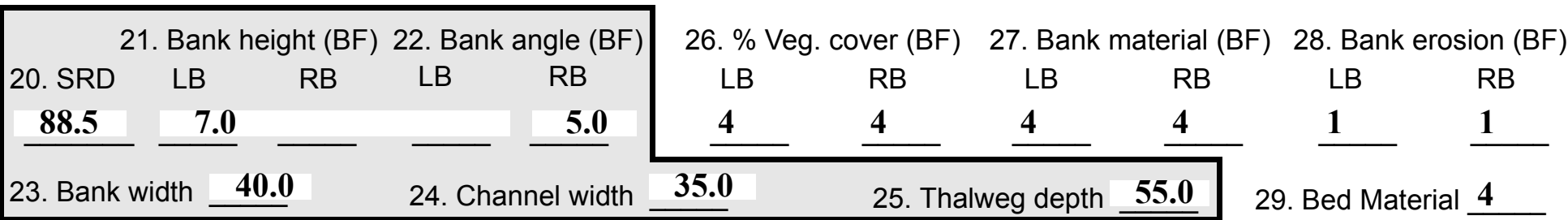

\section{0}

SRD - Section ref. dist. to US face \% Vegetation (Veg) cover: 1- 0 to 25\%; 2- 26 to 50\%; 3- 51 to $75 \% ; 4-76$ to $100 \%$
Bed and bank Material: 0- organics; 1- silt / clay, < 1/16mm; 2- sand, 1/16 - 2mm; 3- gravel, 2 - 64mm;

4- cobble, 64 - 256mm; 5- boulder, > 256mm; 6- bedrock; 7- manmade

Bank Erosion: 0- not evident; 1- light fluvial; 2- moderate fluvial; 3- heavy fluvial / mass wasting

Bank protection types: 0- absent; 1- < 12 inches; 2- < 36 inches; 3- < 48 inches; 4- < 60 inches; 5- wall / artificial levee

Bank protection conditions: 1- good; 2- slumped; 3- eroded; 4- failed

32. Comments (bank material variation, minor inflows, protection extent, etc.):

27. The bank material is cobble, boulder and gravel.

29. The bed material is cobble, gravel, and boulder.

30. The right and left banks have native boulder and cobble protection. 
33.Point/Side bar present? $\mathbf{N}(Y$ or $N$. if $N$ type ctrl-n pb)34. Mid-bar distance: -

35. Mid-bar width: -

36. Point bar extent: feet (US, UB) to feet (US, UB, DS) positioned $\%$ LB to $\% \mathrm{RB}$

37. Material: -

38. Point or side bar comments (Circle Point or Side; Note additional bars, material variation, status, etc.):

NO POINT BARS

39. Is a cut-bank present? $\underline{\mathbf{N}}$ (Y or if $\mathrm{N}$ type ctrl-n cb)

40. Where? (LB or $R B)$

41. Mid-bank distance: -

42. Cut bank extent: feet (US, UB) to feet (US, UB, DS)

43. Bank damage: (1- eroded and/or creep; 2- slip failure; 3- block failure)

44. Cut bank comments (eg. additional cut banks, protection condition, etc.):

There is light fluvial erosion on the left bank.

\section{Is channel scour present? $\mathbf{N}$ ( $Y$ or if $N$ type ctrl-n cs)}

47. Scour dimensions: Length Width Depth : 46. Mid-scour distance: -

48. Scour comments (eg. additional scour areas, local scouring process, etc.):

NO CHANNEL SCOUR

49. Are there major confluences? $\mathbf{N}$

51. Confluence 1: Distance Confluence 2: Distance 52. Enters on Enters on 54. Confluence comments (eg. confluence name):

\section{NO MAJOR CONFLUENCES}

50. How many? -

53. Type(1-perennial; 2- ephemeral)

Type (1-perennial; 2-ephemeral)

\section{Under Bridge Channel Assessment}

55. Channel restraint (BF)? LB 2

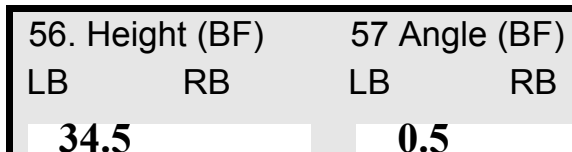

58. Bank width (BF) (1- natural bank; 2- abutment; 3- artificial levee)

Bed and bank Material: 0- organics; 1- silt / clay, < 1/16mm; 2- sand, 1/16 - 2mm; 3- gravel, 2 - 64mm; 4- cobble, 64 - 256mm; 5- boulder, > 256mm; 6- bedrock; 7- manmade

61. Material (BF) 62. Erosion (BF)

LB RB LB RB

$\underline{2} \quad \underline{7} \quad \underline{0}$

Bank Erosion: 0- not evident; 1- light fluvial; 2- moderate fluvial; 3- heavy fluvial / mass wasting

64. Comments (bank material variation, minor inflows, protection extent, etc.):

3

The downstream end of the right abutment footing is exposed.

63. The bed material is gravel, cobble, sand, silt and clay. 
65. Debris and Ice Is there debris accumulation?

$(Y$ or $N)$ 66. Where? $\mathbf{N}$

(1- Upstream; 2- At bridge; 3- Both)

67. Debris Potential ( 1- Low; 2- Moderate; 3- High)

69. Is there evidence of ice build-up? 1 (Y or N)

68. Capture Efficiency 2

(1-Low; 2- Moderate; 3- High)

70. Debris and Ice Comments:

Ice Blockage Potential $\mathbf{N}$

(1-Low; 2-Moderate; 3- High)

1

There is a high stream slope with trees along the upstream banks.

\begin{tabular}{|l|l|l|l|l|c|c|c|c|}
\hline Abutments & $\begin{array}{c}71 . \text { Attack } \\
\angle \text { (BF) }\end{array}$ & $\begin{array}{c}72 . \text { Slope } \angle \\
\text { (Qmax) }\end{array}$ & $\begin{array}{c}\text { 73. Toe } \\
\text { loc. (BF) }\end{array}$ & $\begin{array}{c}\text { 74. Scour } \\
\text { Condition }\end{array}$ & $\begin{array}{c}75 . \text { Scour } \\
\text { depth }\end{array}$ & $\begin{array}{c}\text { 76. Exposure } \\
\text { depth }\end{array}$ & 77. Material & 78. Length \\
\hline LABUT & - & $\mathbf{9 0}$ & $\mathbf{2}$ & $\mathbf{0}$ & - & - & $\mathbf{1}$ & $\mathbf{9 0 . 0}$ \\
\hline RABUT & $\mathbf{1 0}$ & $\mathbf{9 0}$ & $\mathbf{2}$ & & & $\mathbf{2}$ & $\mathbf{1}$ & $\mathbf{3 1 . 0}$ \\
\hline
\end{tabular}

Pushed: $L B$ or RB

Toe Location (Loc.): 0- even, 1- set back, 2- protrudes

Scour cond.: 0- not evident; 1- evident (comment); 2- footing exposed; 3-undermined footing; 4- piling exposed; 5- settled; 6- failed

Materials: 1- Concrete; 2- Stone masonry or drywall; 3- steel or metal; 4- wood

79. Abutment comments (eg. undermined penetration, unusual scour processes, debris, etc.):

0

1

The Top of the right abutment footing is exposed at the downstream end. However, the bed elevation is flush with the footing so exposure depth is zero. The scour depth is $1 \mathrm{ft}$ since the water depth at the downstream right end of the bridge face is about $1 \mathrm{ft}$ deeper than the thalweg depth upstream and downstream. The thalweg depths under the bridge are almost $0.5 \mathrm{ft}$ deeper than upstream or downstream which may indicate some remnant contraction scour.

80. Wingwalls:

Exist? Material? Scour Scour Exposure $\begin{aligned} & 81 . \\ & \text { Angle? Length? }\end{aligned}$ Condition? depth? depth?

USLWW:

$$
\text { Condition? depth? }
$$

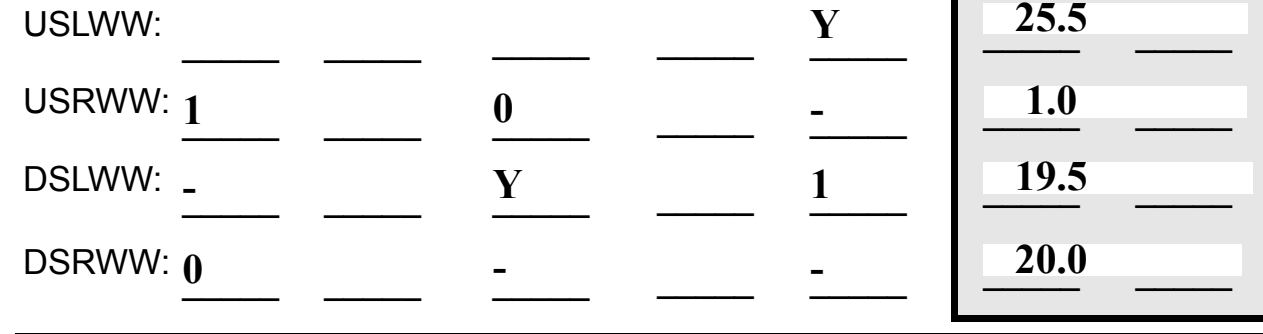

Wingwall materials: 1- Concrete; 2- Stone masonry or drywall; 3- steel or metal; 4- wood

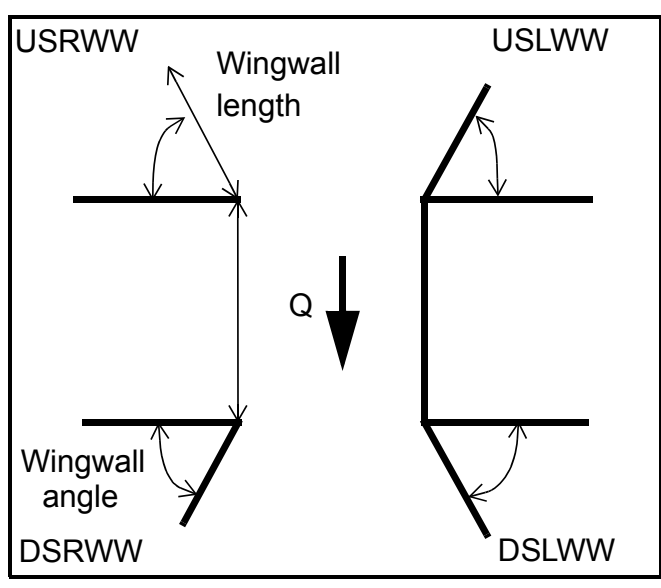

82. Bank / Bridge Protection:

\begin{tabular}{|l|l|l|l|l|l|l|l|c|}
\hline Location & USLWW & USRWW & LABUT & RABUT & LB & RB & DSLWW & DSRWW \\
\hline Type & Y & - & $\mathbf{1}$ & $\mathbf{0}$ & - & - & - & - \\
\hline Condition & $\mathbf{1}$ & - & $\mathbf{2}$ & $\mathbf{0}$ & $\mathbf{0}$ & $\mathbf{0}$ & $\mathbf{0}$ & - \\
\hline Extent & $\mathbf{0}$ & $\mathbf{Y}$ & $\mathbf{1}$ & - & - & - & - & - \\
\hline
\end{tabular}

Bank / Bridge protection types: 0- absent; 1- < 12 inches; 2- < 36 inches; 3- < 48 inches; 4- < 60 inches; 
83. Wingwall and protection comments (eg. undermined penetration, unusual scour processes, etc.):

-
-
-
-
-
-
0
-
-

There is no protection besides fluvially deposited cobbles and boulders at the upstream wingwalls.

\section{Piers:}

84. Are there piers? (Y or if $N$ type ctrl-n pr)

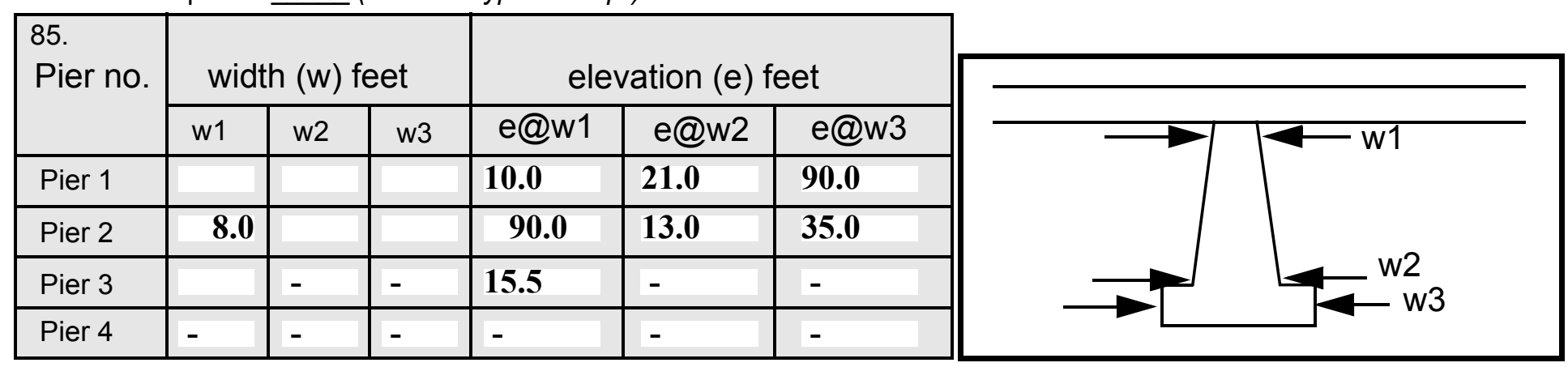

\begin{tabular}{|l|l|l|l|l|}
\hline Level 1 Pier Descr. & 1 & \multicolumn{1}{|c|}{2} & 3 & \multicolumn{1}{|c|}{} \\
\hline 86. Location (BF) & & - & - & - \\
\hline 87. Type & & - & - & - \\
\hline 88. Material & & - & - & - \\
\hline 89. Shape & & - & - & - \\
\hline 90. Inclined? & & - & - & - \\
\hline 91. Attack $\angle$ (BF) & & - & - & - \\
\hline 92. Pushed & & - & - & - \\
\hline 93. Length (feet) & - & - & - & - \\
\hline 94. \# of piles & & - & - & - \\
\hline 95. Cross-members & & - & - & - \\
\hline 96. Scour Condition & N & - & - & - \\
\hline 97. Scour depth & - & - & - & - \\
\hline 98. Exposure depth & - & - & - & - \\
\hline
\end{tabular}

LFP, LTB, LB, MCL, MCM, MCR, RB, RTB, RFP

1- Solid pier, 2- column, 3- bent

1-Wood; 2- concrete; 3- metal; 4- stone

1- Round; 2- Square; 3- Pointed

Y-yes; $N$ - no

$L B$ or $R B$

0- none; 1- laterals; 2- diagonals; 3- both

0- not evident; 1- evident (comment);

2- footing exposed; 3- piling exposed;

4- undermined footing; 5- settled; 6- failed 
99. Pier comments (eg. undermined penetration, protection and protection extent, unusual scour processes, etc.):

-
-
-
-
-
-
-
-
-

100.

\section{E. Downstream Channel Assessment}

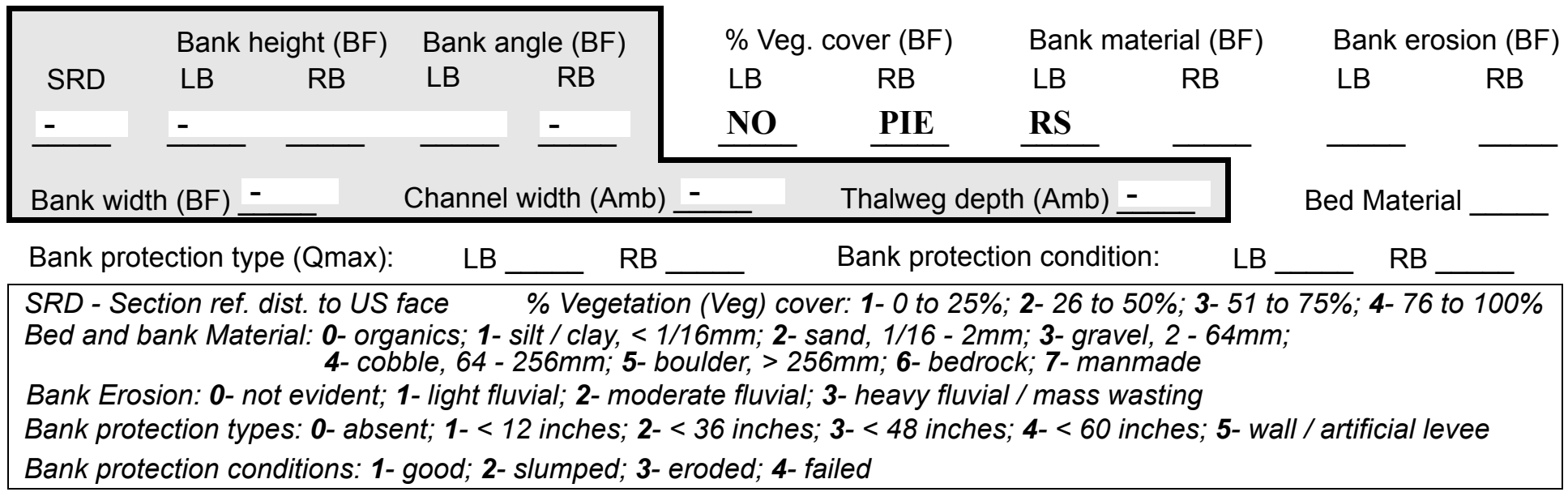

Comments (eg. bank material variation, minor inflows, protection extent, etc.):

$\mathbf{3}$
$\mathbf{2}$
$\mathbf{3}$
$\mathbf{3}$
$\mathbf{3}$
$\mathbf{0}$
$\mathbf{4}$
$\mathbf{0}$
$\mathbf{0}$
-
-

The bank material is gravel, boulder and sand.

The bed material is cobble gravel and boulder.

There are large boulders scattered on the right bank downstream that appear fluvially deposited and provide

101. Is a drop structure present? so ( $Y$ or $N$, if $N$ type ctrl-n ds) 102. Distance: ___ feet

103. Drop: - feet 104. Structure material: me (1- steel sheet pile; 2- wood pile; 3- concrete; 4- other)

105. Drop structure comments (eg. downstream scour depth):

bank and road embankment protection. 
Point bar extent: feet

(US, UB, DS) to feet $\underline{\mathbf{N}}$ (US, UB, DS) positioned \%LB to NO \%RB

Material: DR

Point or side bar comments (Circle Point or Side) note additional bars, material variation, status, etc.):

\section{OP STRUCTURE}

Is a cut-bank present? (Y or if $N$ type ctrl- $n$ cb) Where? (LB or $R B)$

Mid-bank distance: $\underline{\mathbf{Y}}$

Cut bank extent: $\underline{40}$ feet $\underline{\mathbf{2 0}}$ (US, UB, DS) to $\underline{14}$ feet $\underline{\mathbf{U B}}$ (US, UB, DS)

Bank damage: 48 (1-eroded and/or creep; 2- slip failure; 3- block failure)

Cut bank comments (eg. additional cut banks, protection condition, etc.):

DS

O

30

3

Is channel scour present? ___ (Y or if N type ctrl-n cs) Mid-scour distance: The

Scour dimensions: Length side Width $\underline{\text { bar }}$ Depth: $\underline{\text { here }} \quad$ Positioned $\underline{\text { is }}$ \%LB to loca $\%$ RB

Scour comments (eg. additional scour areas, local scouring process, etc.):

ted in a position where gravel has aggraded from an intermittent confluence entering at this location on the bank. The side bar material is gravel and cobble.

Are there major confluences? $\mathbf{Y}$ ( $Y$ or if $N$ type ctrl-n $m c)$

Confluence 1: Distance 66 Enters on $\underline{45}$ ( $L B$ or $R B)$

How many? $\underline{\mathbf{L B}}$

Confluence 2: Distance 100

Enters on DS ( $L B$ or RB)

Type $\underline{\mathbf{D S}}$

(1- perennial; 2- ephemeral)

Confluence comments (eg. confluence name):

Type 2 (1-perennial; 2- ephemeral)

A large slip failure (landslide) on the outside of the channel bend.

\section{F. Geomorphic Channel Assessment}

107. Stage of reach evolution

1- Constructed

2- Stable

3- Aggraded

4- Degraded

5- Laterally unstable

6- Vertically and laterally unstable 
108. Evolution comments (Channel evolution not considering bridge effects; See HEC-20, Figure 1 for geomorphic descriptors):

$\mathbf{N}$

$-$

-

$-$

$-$

$-$

There may be some contraction scour under the bridge since the thalweg depths at the upstream and downstream faces are almost $0.5 \mathrm{ft}$ deeper than the thalweg depths upstream and downstream.

$\mathbf{Y}$ 


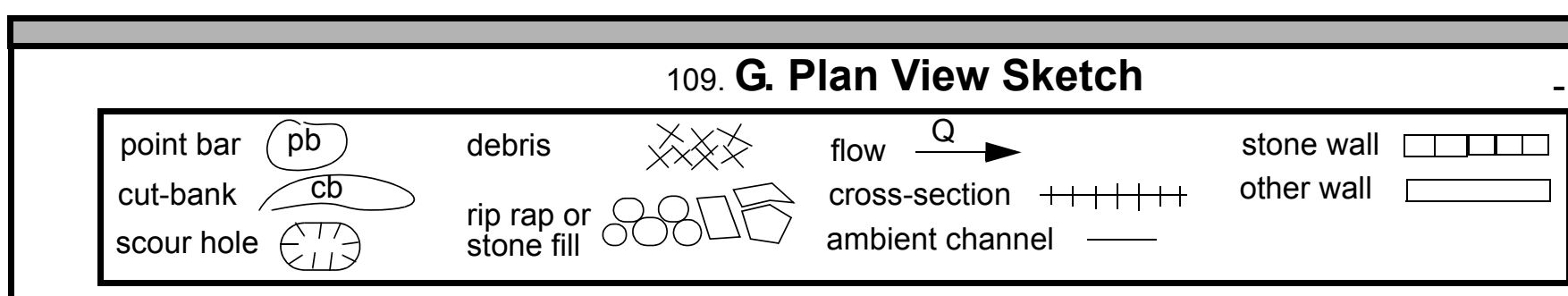

cut-bank $\mathrm{cb}$

scour hole rip rap or stone fill $000 \mathrm{~L}$ cross-section $+1+1+1$ ambient channe other wall 
APPENDIX F:

SCOUR COMPUTATIONS 


\begin{tabular}{|c|c|c|c|}
\hline $\begin{array}{ll}\text { Structure Number: } & \text { BRNATH00290034 } \\
\text { Road Number: } & \text { TH } 29\end{array}$ & & $\begin{array}{l}\text { Town: } \\
\text { County: }\end{array}$ & $\begin{array}{l}\text { Barnard } \\
\text { Windsor }\end{array}$ \\
\hline Stream: Locust Creek & & & \\
\hline Initials MAI & Checked: & EMB & \\
\hline lalysis of contraction scour, live- & bed or $\mathrm{cle}$ & ear wate & \\
\hline Critical Velocity of Bed Material ( & converted & to Engl: & sh units) \\
\hline (Richardson and others, 1995, p. 28 & , eq. 16) & & \\
\hline Approach Section & & & \\
\hline Characteristic & $100 \mathrm{yr}$ & $500 \mathrm{yr}$ & other $Q$ \\
\hline Total discharge, cfs & 2350 & 3050 & 2970 \\
\hline Main Channel Area, ft2 & 400.6 & 607.9 & 493 \\
\hline Left overbank area, ft2 & 0 & 0 & 0 \\
\hline Right overbank area, ft2 & 0 & 0 & 0 \\
\hline Top width main channel, ft & 59.5 & 68.4 & 63.6 \\
\hline Top width L overbank, ft & 0 & 0 & 0 \\
\hline Top width $\mathrm{R}$ overbank, ft & 0 & 0 & 0 \\
\hline D50 of channel, ft & 0.293 & 0.293 & 0.293 \\
\hline D50 left overbank, ft & 0 & 0 & 0 \\
\hline D50 right overbank, ft & 0 & 0 & 0 \\
\hline y1, average depth, $M C$, ft & 6.7 & 8.9 & 7.8 \\
\hline Y1, average depth, LOB, ft & ERR & ERR & ERR \\
\hline Y1, average depth, ROB, ft & ERR & ERR & ERR \\
\hline Total conveyance, approach & 33319 & 60195 & 44795 \\
\hline Conveyance, main channel & 33319 & 60195 & 44795 \\
\hline Conveyance, LOB & 0 & 0 & 0 \\
\hline Conveyance, ROB & 0 & 0 & 0 \\
\hline Percent discrepancy, conveyeance & 0.0000 & 0.0000 & 0.0000 \\
\hline Qm, discharge, $\mathrm{MC}$, cfs & 2350.0 & 3050.0 & 2970.0 \\
\hline Q1, discharge, LOB, Cfs & 0.0 & 0.0 & 0.0 \\
\hline Qr, discharge, ROB, cfs & 0.0 & 0.0 & 0.0 \\
\hline $\mathrm{Vm}$, mean velocity $\mathrm{MC}$, ft/s & 5.9 & 5.0 & 6.0 \\
\hline $\mathrm{Vl}$, mean velocity, LOB, ft/s & ERR & ERR & ERR \\
\hline Vr, mean velocity, ROB, ft/s & ERR & ERR & ERR \\
\hline Vc-m, crit. velocity, MC, ft/s & 10.2 & 10.7 & 10.5 \\
\hline Vc-l, crit. velocity, LOB, ft/s & $\mathrm{N} / \mathrm{A}$ & $\mathrm{N} / \mathrm{A}$ & $\mathrm{N} / \mathrm{A}$ \\
\hline Vc-r, crit. velocity, ROB, ft/s & $\mathrm{N} / \mathrm{A}$ & $\mathrm{N} / \mathrm{A}$ & $\mathrm{N} / \mathrm{A}$ \\
\hline Results & & & \\
\hline Live-bed(1) or Clear-Water(0) Contr & action $\mathrm{ScC}$ & our? & \\
\hline Main Channel & 0 & 0 & 0 \\
\hline Left Overbank & $\mathrm{N} / \mathrm{A}$ & $\mathrm{N} / \mathrm{A}$ & $\mathrm{N} / \mathrm{A}$ \\
\hline Right Overbank & $\mathrm{N} / \mathrm{A}$ & $\mathrm{N} / \mathrm{A}$ & $\mathrm{N} / \mathrm{A}$ \\
\hline
\end{tabular}


Clear Water Contraction Scour in MAIN CHANNEL

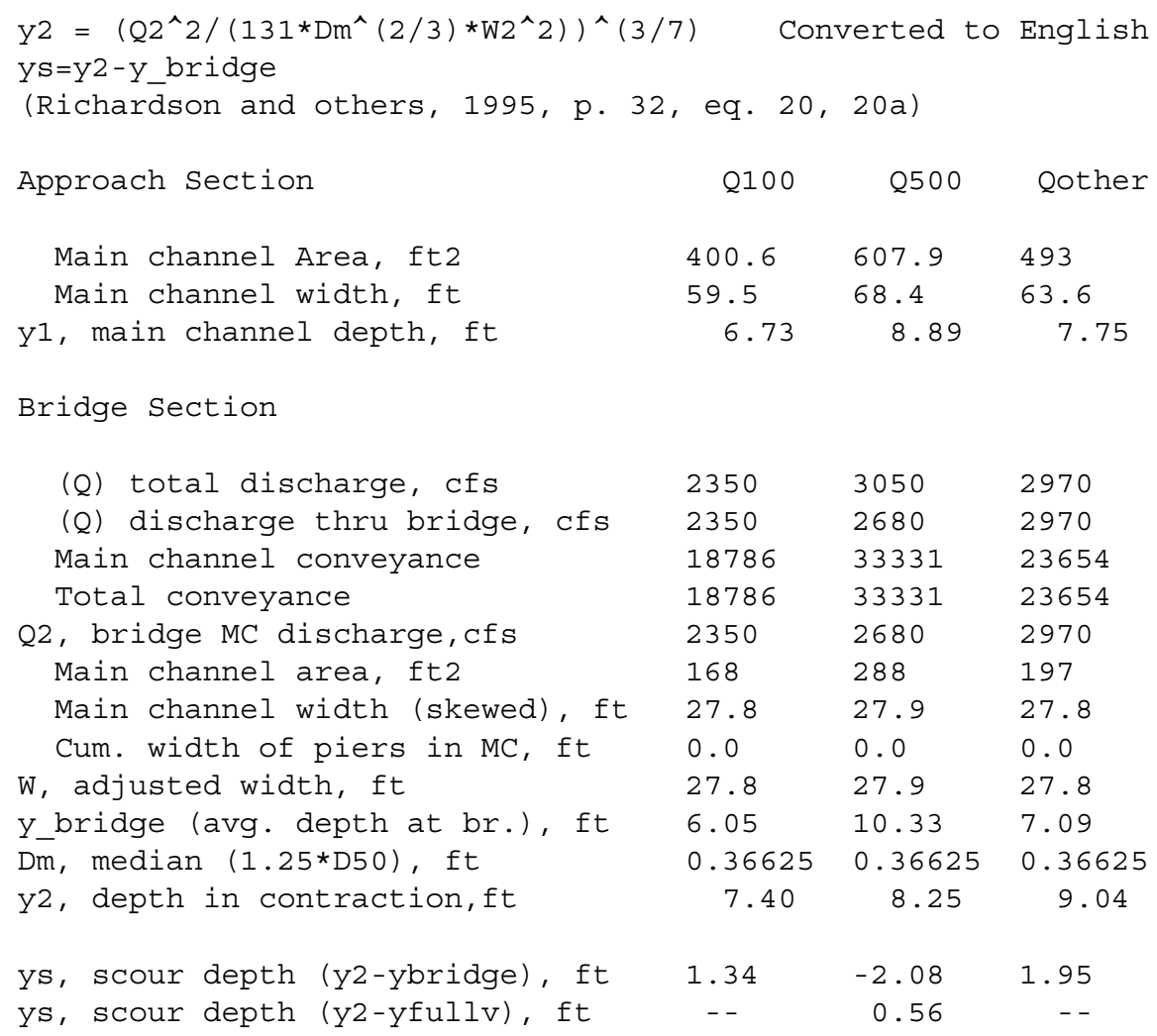

Pressure Flow Scour (contraction scour for orifice flow conditions)

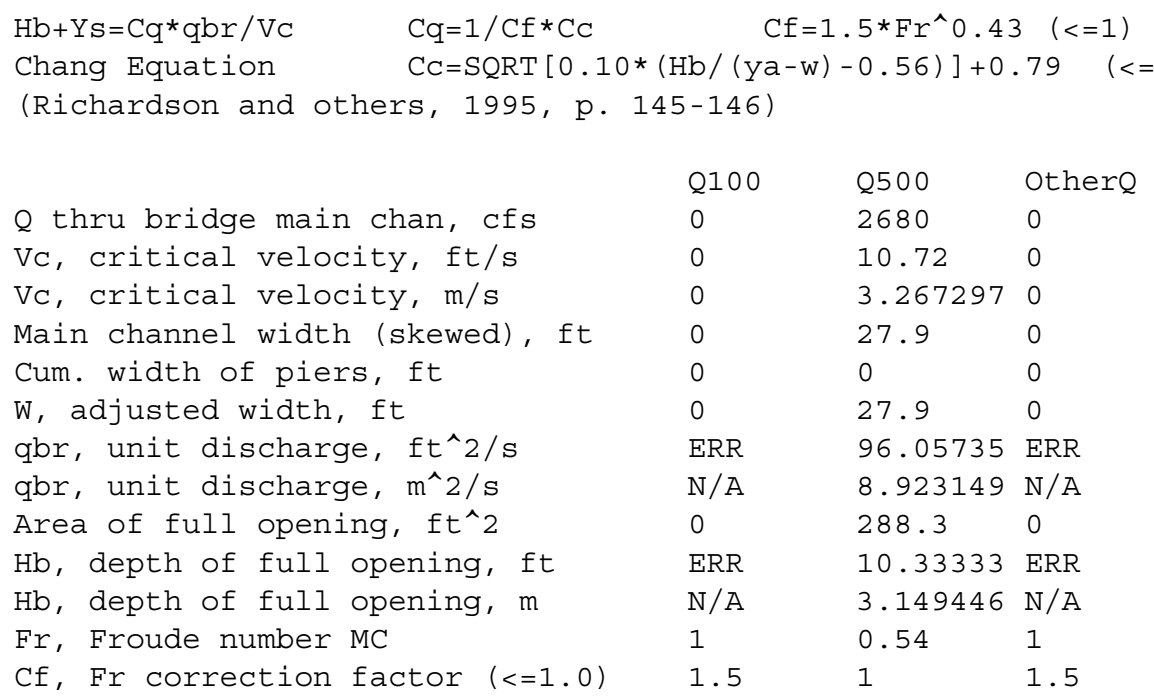




\begin{tabular}{|c|c|c|c|}
\hline \\
\hline Elevation of Low Steel, ft & 0 & 498.84 & 0 \\
\hline Elevation of Bed, ft & $\mathrm{N} / \mathrm{A}$ & 488.5067 & $\mathrm{~N} / \mathrm{A}$ \\
\hline Elevation of approach WS, ft & 0 & 500.77 & 0 \\
\hline HF, bridge to approach, ft & 0 & 0.1 & 0 \\
\hline Elevation of WS immediately US, ft & 0 & 500.67 & 0 \\
\hline ya, depth immediately US, ft & $\mathrm{N} / \mathrm{A}$ & 12.16333 & $\mathrm{~N} / \mathrm{A}$ \\
\hline ya, depth immediately US, m & $\mathrm{N} / \mathrm{A}$ & 3.77978 & $\mathrm{~N} / \mathrm{A}$ \\
\hline Mean elev. of deck, ft & 0 & 500.81 & 0 \\
\hline w, depth of overflow, ft $(>=0)$ & 0 & 0 & 0 \\
\hline Cc, vert contrac correction $(<=1.0)$ & ERR & 0.960161 & ERR \\
\hline Ys, depth of scour (chang), ft & $\mathrm{N} / \mathrm{A}$ & -1.00097 & $\mathrm{~N} / \mathrm{A}$ \\
\hline \multicolumn{4}{|l|}{ ARMORING } \\
\hline D90 & 0.818 & 0.818 & 0.818 \\
\hline D95 & 1.223 & 1.223 & 1.223 \\
\hline Critical grain size,Dc, ft & 0.9694 & 0.3434 & 1.0525 \\
\hline Decimal-percent coarser than Dc & 0.075 & 0.421 & 0.0655 \\
\hline Depth to armoring, ft & 35.87 & 1.42 & 45.05 \\
\hline
\end{tabular}

Abutment scour

Froehlich's Abutment Scour

$\mathrm{Ys} / \mathrm{Y} 1=2.27 * \mathrm{~K} 1 * \mathrm{~K} 2 *\left(\mathrm{a}^{\prime} / \mathrm{Y} 1\right) \wedge 0.43 * \mathrm{Fr} 1 \wedge 0.61+1$

(Richardson and others, 1995, p. 48, eq. 28)

\begin{tabular}{|c|c|c|c|c|c|c|}
\hline \multirow[b]{2}{*}{ Characteristic } & \multicolumn{2}{|c|}{ Left Abutment } & \multicolumn{4}{|c|}{ Right Abutment } \\
\hline & $100 \mathrm{yr}$ & 500 yr & Dther $Q$ & $00 \mathrm{yr}$ & $00 \mathrm{yr} Q$ & ther $Q$ \\
\hline (Qt), total discharge, cfs & 2350 & 3050 & 2970 & 2350 & 3050 & 2970 \\
\hline a', abut.length blocking flow, ft & 12.2 & 16.1 & 14 & 17.7 & 22.7 & 20 \\
\hline Ae, area of blocked flow ft 2 & 60.1 & 106.3 & 79.9 & 98.2 & 151.19 & 126.4 \\
\hline $\begin{array}{l}\text { Qe, discharge blocked abut., cfs } \\
\text { (If using Qtotal_overbank to obta }\end{array}$ & $\begin{array}{l}259.5 \\
\text { ain Ve, }\end{array}$ & $\begin{array}{r}397.6 \\
\text { ave Qe }\end{array}$ & $\begin{array}{l}356.4 \\
\text { ank and }\end{array}$ & $\begin{array}{l}480.7 \\
\text { nter } V \epsilon\end{array}$ & $\begin{array}{c}-- \\
\text { anually }\end{array}$ & 634.5 \\
\hline $\mathrm{Ve},(\mathrm{Qe} / \mathrm{Ae}), \mathrm{ft} / \mathrm{s}$ & 4.32 & 3.74 & 4.46 & 4.90 & 4.17 & 5.02 \\
\hline ya, depth of $f / p$ flow, ft & 4.93 & 6.60 & 5.71 & 5.55 & 6.66 & 6.32 \\
\hline $\begin{array}{l}\text {--Coeff., K1, for abut. type }(1.0, \\
\text { K1 }\end{array}$ & $\begin{array}{l}\text { verti.; } \\
0.82\end{array}$ & $\begin{array}{l}.82, \mathrm{ve} \\
0.82\end{array}$ & $\begin{array}{l}\text { i. w/ w } \\
0.82\end{array}$ & $\begin{array}{l}\text { gwalli } \\
0.82\end{array}$ & $\begin{array}{l}55, \operatorname{spi} \\
0.82\end{array}$ & $\begin{array}{r}\text { thru) } \\
0.82\end{array}$ \\
\hline $\begin{array}{l}\text {--Angle (theta) of embankment } \quad<90 \\
\text { theta } \\
\text { K2 }\end{array}$ & $\begin{array}{l}\text { if abut } \\
65 \\
0.96\end{array}$ & $\begin{array}{l}\text { points } \\
65 \\
0.96\end{array}$ & $\begin{array}{l}i>90 i \\
65 \\
0.96\end{array}$ & $\begin{array}{l}\text { abut. } \\
115 \\
1.03\end{array}$ & $\begin{array}{l}\text { its US) } \\
115 \\
1.03\end{array}$ & $\begin{array}{l}115 \\
1.03\end{array}$ \\
\hline Fr, froude number $\mathrm{f} / \mathrm{p}$ flow & 0.343 & 0.257 & 0.329 & 0.366 & 0.274 & 0.352 \\
\hline ys, scour depth, ft & 11.68 & 14.14 & 13.31 & 15.06 & 16.50 & 16.86 \\
\hline $\begin{array}{l}\text { HIRE equation }\left(\mathrm{a}^{\prime} / \mathrm{ya}>25\right) \\
\mathrm{ys}=4 * \mathrm{Fr}^{\wedge} 0.33^{*} \mathrm{Y} 1 * \mathrm{~K} / 0.55 \\
\text { (Richardson and others, 1995, p. } 4 \mathrm{~S}\end{array}$ & 9 , eq. 2 & & & & & \\
\hline a' (abut length blocked, ft) & 12.2 & 16.1 & 14 & 17.7 & 22.7 & 20 \\
\hline y1 (depth f/p flow, ft) & 4.93 & 6.60 & 5.71 & 5.55 & 6.66 & 6.32 \\
\hline$a^{\prime} / y_{1}$ & 2.48 & 2.44 & 2.45 & 3.19 & 3.41 & 3.16 \\
\hline Skew correction & 0.92 & 0.92 & 0.92 & 1.08 & 1.08 & 1.08 \\
\hline Froude no. f/p flow & 0.34 & 0.26 & 0.33 & 0.37 & 0.27 & 0.35 \\
\hline $\begin{array}{c}\text { Ys w/ corr. factor K1/0.55: } \\
\text { vertical }\end{array}$ & ERR & ERR & ERR & ERR & ERR & ERR \\
\hline vertical w/ ww's & $\mathrm{ERR}$ & ERR & ERR & ERR & ERR & ERR \\
\hline spill-through & ERR & ERR & ERR & ERR & ERR & ERR \\
\hline
\end{tabular}




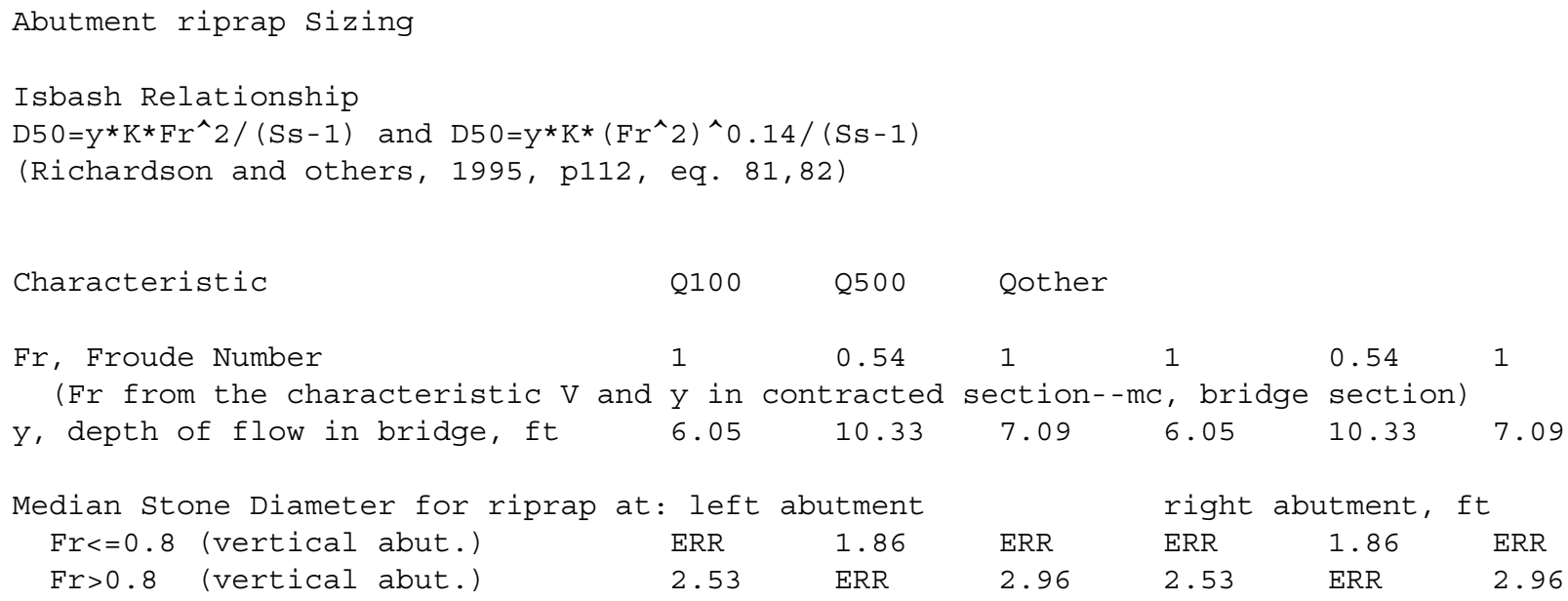

